\title{
MIGRATION AND ECONOMIC MOBILITY IN TANZANIA: EVIDENCE FROM A TRACKING SURVEY
}

\author{
Kathleen Beegle, Joachim De Weerdt, and Stefan Dercon*
}

\begin{abstract}
This study explores to what extent migration has contributed to improved living standards of individuals in Tanzania. Using a thirteenyear panel survey, we find that migration between 1991 and 2004 added 36 percentage points to consumption growth. Although moving out of agriculture resulted in much higher growth than staying in agriculture, growth was always greater in any sector if the individual physically moved. As to why more people do not move given the high returns to geographical mobility, analysis finds evidence consistent with models in which exit barriers set by home communities prevent the migration of some categories of people.
\end{abstract}

\section{Introduction}

$\mathrm{F}$ INDING routes out of poverty remains a key issue for households and policymakers alike. A long-term vision of development suggests that poverty reduction is associated with intergenerational mobility out of rural areas and agriculture and into urban nonagricultural settings. Physical and economic mobility seem to go hand-in-hand. Standard economic theory has multiple narratives of how physical and economic mobility interact. The Lewis model offers a stylized description of rural transformation, with sector mobility of labor from agriculture into "modern" production processes. At least in its original specification, the model suggests an initial gap in earnings between rural and urban locations (Lewis, 1954). ${ }^{1}$ The Harris-Todaro model emphasizes the migration process and the fact that relative individual earnings incentives matter, so that both pull and push factors drive migration. A gap between rural and expected urban earnings drives migration. Unemployment (or an informal sector offering low earnings) would nevertheless allow an actual gap between urban and rural wages to persist, with the premium a function of the unemployment rate (Harris \& Todaro, 1970). Other work, such as on the "new economics of migration" (Stark \& Bloom, 1985), emphasizes that migration is part of a general livelihood strategy for the initial household as a whole. Migration is part of a welfare-maximizing strategy with a clear role for overall household income growth, but also a role for risk sharing. For example, Rosenzweig and Stark (1989) find

Received for publication December 31, 2008. Revision accepted for publication March 16, 2010.

* Beegle: World Bank; De Weerdt: EDI, Tanzania; Dercon: Oxford University.

We thank Karen Macours, David McKenzie, Peter Neary, two anonymous referees, the editor of this journal, and seminar participants at the Massachusetts Avenue Development Seminar, Oxford University, and the World Bank for very useful comments. All views are our own and do not necessarily reflect the views of the World Bank or its member countries.

${ }^{1}$ For example, Lewis (1954, p. 150) wrote: "Earnings in the subsistence sector set a floor to wages in the capitalist sector, but in practice wages have to be higher than this, and there is usually a gap of 30 per cent or more between capitalist wages and subsistence earnings." that migration patterns for marriage in rural India are consistent with the risk-sharing strategies of the initial household. Recent evidence has highlighted not just the role of networks in facilitating migration from home areas, but also how migration is closely linked to migrants' access to social networks in destination areas (Munshi, 2003) and to community rates of out-migration (Kilic et al., 2009).

Although the emphasis on the process of migration in most recent empirical work has provided many insights, few of these studies convincingly address the question of whether migration leads to improved living conditions. A major problem is having access to data that allow a careful and convincing assessment of the relative welfare of migrants and nonmigrants, due to the standard evaluation problem: an individual cannot be observed to be both a migrant and a nonmigrant. A few studies have access to experimental data, such as international migration lotteries (McKenzie, Gibson, \& Stillman, 2010), but most studies have to work with nonexperimental data. Without experimental data, the key concern, unobserved heterogeneity affecting both outcomes and the process of migration, persists. This leads to the quest for imaginative and convincing instruments for migration (see the review of the migration and poverty literature by McKenzie \& Sasin, 2007). An additional hurdle is the need for panel data to study migration and economic mobility. The costs and difficulties of resurveying means that attrition may be relatively high for this group and may also result in the loss of some of the most relevant households for the study of this process (Beegle, 2000; Rosenzweig, 2003).

This paper uses unique data from a region in Tanzania to address the question, What is the impact on poverty and wealth of physical movement out of the original community? Although we do not have experimental data, the nature of our data allows us to limit the potential sources of unobserved heterogeneity. Building on a detailed panel survey conducted in the early 1990s, we reinterviewed individuals in 2004, making a notable effort to track individuals who had moved.

The tracking of individuals to new locations proves crucially important for assessing welfare changes among the baseline sample. The average consumption change of individuals who migrated was more than four times greater than that of individuals who did not move. Those who had moved out of Kagera by 2004 experienced consumption growth that was ten times greater compared with those who remained in their original community. These averages translate into very different patterns of poverty dynamics for the physically mobile and immobile. For those who stayed in the community, the poverty rate decreased by about 4 percentage points over the thirteen years. For those 
who moved elsewhere within the region, the poverty rate decreased by about 12 percentage points, and for those who moved out of the region, the poverty rate decreased by 23 percentage points. Had we not tracked and interviewed people who moved out of the community, a practice that is not carried out in many panel surveys, we would have seriously underestimated the extent to which poverty decreased during 1991 to 2004 in Kagera; we would have reported poverty reduction at about half its true value. Clemens and Pritchett (2008) raise similar concerns in the context of income growth and international migration. Furthermore, the tracking and reinterviewing enabled us to collect valuable information about pathways out of poverty.

Still, these statistics do not provide evidence that moving out of the community leads to higher income growth. As noted above, we cannot observe the counterfactual: What would income growth have been for migrants had they not migrated? We exploit some unique features of the data to address concerns about unobserved heterogeneity. First, individual fixed-effects regressions for movers and stayers produce a difference-in-difference estimation of the impact of physical movement, controlling for any fixed individual factors that affect consumption. Second, we can control for initial household fixed effects in the growth rate of consumption because we observe baseline households in which some individuals migrate and others do not. This controls for observable and unobservable factors fixed to the family that can affect the growth rate of consumption. Thus, we identify the impact of migration on income using withinhousehold variation in migration. Unlike most other studies of migration, our identification does not rely on household shocks, distances to possible destinations, or the existence of family networks at the destination to identify the migration decision. Such variables are likely to have an impact on the income of those migrating as well as those staying behind, and so the exclusion restriction will not be satisfied. In our study, we are able to move beyond these approaches; in addition to using panel data on migrants and nonmigrants, we compare siblings and other relatives who were living together at the baseline.

These estimations address many possible sources of heterogeneity, such as (genetic) health and ability endowments; risk aversion; wealth constraints; and market, risk, and environmental circumstances. We find that movement out of the community results in $36 \%$ higher consumption relative to staying. Comparison of the results with and without fixed effects suggests that migrants are more likely to be from families with greater potential for growth in earnings.

A weakness of this approach, however, is the implicit assumption that within families, migration is random, which is a strong assumption. For example, in view of the standard Harris-Todaro model of individual migration, earnings differentials drive migration, so those who are observed to have migrated from within a household tend to have had greater earning potential than those who stayed behind, implying that within-family migration may not be random. ${ }^{2}$ We use two-stage least squares (2SLS) methods to deal with this potential endogeneity. We assert that opportunities to migrate depend on the interaction of household circumstances with the individual's status and position within the household at baseline. The 2SLS estimates show limited evidence of unobserved individual heterogeneity affecting consumption growth. In short, unobservables at the household level correlated with growth potential appear to matter, whereas individual heterogeneity does not.

We explore two additional avenues of interest. First, does migration to urban areas drive the results? Second, does migration capture changes in the sector of work that would explain the consumption growth we observe? We find suggestive evidence that physical mobility has an independent effect beyond its association with moving out of agriculture or moving to a more urban area. We use these results in conjunction with the literature on network externalities and poverty traps to explain why, if migration has such large payoffs, more people do not move. We conclude that the findings are consistent with models in which exit barriers are set by home communities (through social and family norms), preventing migration of certain categories of people when windows of opportunity arise. Being willing and able to leave behind what you know appears to be a strong determinant of economic mobility. There is no evidence of financial constraints to migration.

In the next section, we provide the context of changes in economic fortunes in Tanzania in the past decade. Section III presents the data used in the analysis, and section IV provides the basic indicators we use to assess economic and welfare changes. Section V briefly describes the method we use to assess the impact of migration, section VI presents the results, and section VII carries out some robustness checks. Section VIII builds a narrative around the regressions and aims to explain why more people do not migrate when the benefits of doing so are so high.

\section{The Setting: Tanzania and Kagera, 1994-2004}

Between 1994 and 2004, Tanzania experienced a period of relatively rapid macroeconomic growth, attributed to liberalization, a renewed trade orientation, a stable political context, and a relatively positive business climate that helped to boost economic performance. Real GDP growth was on the order of $4.2 \%$ per year between 1994 and 2004, and annual population growth was around $3.2 \%$ (United Republic of Tanzania, 2004). There is also evidence that growth accelerated in the last few years of the period compared with the 1990s. However, growth was not sufficiently broad-based to result in rapid poverty reduction. On the basis of the available evidence, poverty rates declined only slightly, and most of the progress in poverty reduction was

\footnotetext{
${ }^{2}$ This is correct, even if, in equilibrium, when no further migration takes place, expected earnings are equal.
} 
in urban areas. According to the Household Budget Survey (HBS), between 1991 and 2000/01, poverty declined from $39 \%$ to $36 \%$ in mainland Tanzania. The decline in poverty was steep in Dar es Salaam (from 28\% to $18 \%$ ) but minimal in rural Tanzania (from $41 \%$ to $39 \%$ ).

For the purposes of this study, it is useful to consider the Kagera region specifically. The region is far from the capital and the coast, bordering Lake Victoria, Rwanda, Burundi, and Uganda. It is overwhelmingly rural and primarily engaged in producing bananas and coffee in the north and rain-fed annual crops (maize, sorghum, and cotton) in the south. Relatively low-quality coffee exports and agricultural produce are the main sources of income. Mean per capita consumption was near the mean of mainland Tanzania in 2000. Likewise, the region appeared to mirror the rest of the country in terms of growth and poverty reduction: real GDP growth was just over 4\% per year between 1994 and 2004, while poverty in Kagera is estimated to have fallen from $31 \%$ to $29 \%$ between 1991 and 2000/01 (Demombynes \& Hoogeveen, 2007).

The challenges of poverty reduction in Kagera seem to be representative for provincial Tanzania as a whole: some pockets, such as Dar es Salaam, have had substantial growth and poverty reduction, but this has not spread to other areas. This reflects the typical problem of landlocked, agriculture-based economies: how to deliver poverty reduction if the main engine of growth appears to be elsewhere (De Weerdt, 2010).

\section{The Data}

The Kagera Health and Development Survey (KHDS) was originally conducted by the World Bank and Muhimbili University College of Health Sciences (MUCHS) and consisted of about 915 households interviewed up to four times from fall 1991 to January 1994 at intervals of six to seven months (see World Bank, 2004, and http:// www.worldbank.org/lsms/). The KHDS 1991-1994 serves as the baseline data for this paper. Initially designed to assess the impact of the health crisis linked to the HIVAIDS epidemic in the area, it used a stratified design to ensure relatively appropriate sampling of households with adult mortality. Comparisons with the 1991 HBS suggest that in terms of basic welfare and other indicators, the KHDS can be used as a representative sample for this period for Kagera (although not necessarily for the rest of Tanzania; the results are available on request).

The objective of the KHDS 2004 survey was to reinterview all individuals who were household members in any round of the KHDS 1991-1994 and who were alive at the last interview (Beegle, De Weerdt, \& Dercon, 2006). This effectively meant turning the original household survey into an individual longitudinal survey. Each household in which any of the panel individuals lived would be administered the full household questionnaire. Because the set of household members at the baseline had subsequently moved, and usually not as a unit, the 2004 round had more than 2,700 household interviews (from the baseline sample of 912 households).

Although the KHDS is a panel of respondents and the concept of a "household" after ten to thirteen years is a vague notion, it is common in panel surveys to consider recontact rates in terms of households. Excluding households in which all previous members were deceased (17 households with 27 people), the field team managed to recontact $93 \%$ of the baseline households. This is an excellent rate of recontact compared with panel surveys in low-income and highincome countries. The KHDS panel has an attrition rate that is much lower than that of other well-known panel surveys summarized in Alderman et al. (2001), in which the rates ranged from $17.5 \%$ attrition per year to the lowest rate of $1.5 \%$ per year, with most of these surveys covering considerably shorter time periods (two to five years).

Figure 1 charts the evolution of households from the baseline to 2004. Half of all households interviewed were tracking cases, meaning they did not reside in the baseline communities. Of those households tracked, only $38 \%$ were located nearby the baseline community. Overall, $32 \%$ of all households were neither located in nor relatively close to the baseline communities. While tracking is costly, it is an important exercise because migration and dissolution of households are often hypothesized to be important responses to hardship and a strategy for escaping poverty. Excluding these households in the sample raises obvious concerns regarding the selectivity of attrition. In particular, out-migration from the village, dissolution of households, and even marriage may be responses to changing economic or family circumstances. Tracking surveys provide a unique opportunity to study these responses: who uses them, their effects, and whether they get people out of poverty.

Turning to the recontact rates of the sample of 6,352 respondents, table 1 shows the status of the respondents by age group (based on their age at first interview in the 19911994 rounds). The surviving older respondents were much more likely to be located, which is consistent with higher migration rates among the young adults in the sample. Among the youngest respondents, more than three-quarters were successfully reinterviewed. Excluding people who died, $82 \%$ of all respondents were reinterviewed. Table 2 shows the location of the respondents. Without tracking, reinterview rates of surviving respondents would have fallen from $82 \%$ to $52 \%$ (2,780 of 5,394 survivors). Nonlocal migration is important: restricting the tracking to nearby villages would have resulted in $63 \%$ recontact of survivors. Migration also proved to be an important factor in determining whether someone was recontacted. Respondents who were not traced were much more likely to reside outside Kagera (43\%) compared with their counterparts who were reinterviewed (8\%).

The consumption data come from an extensive consumption module administered in 1991 and again in 2004. The consumption aggregate includes home-produced and pur- 
Figure 1.-KHDS 2004: Recontacting Respondents after Ten or More Years

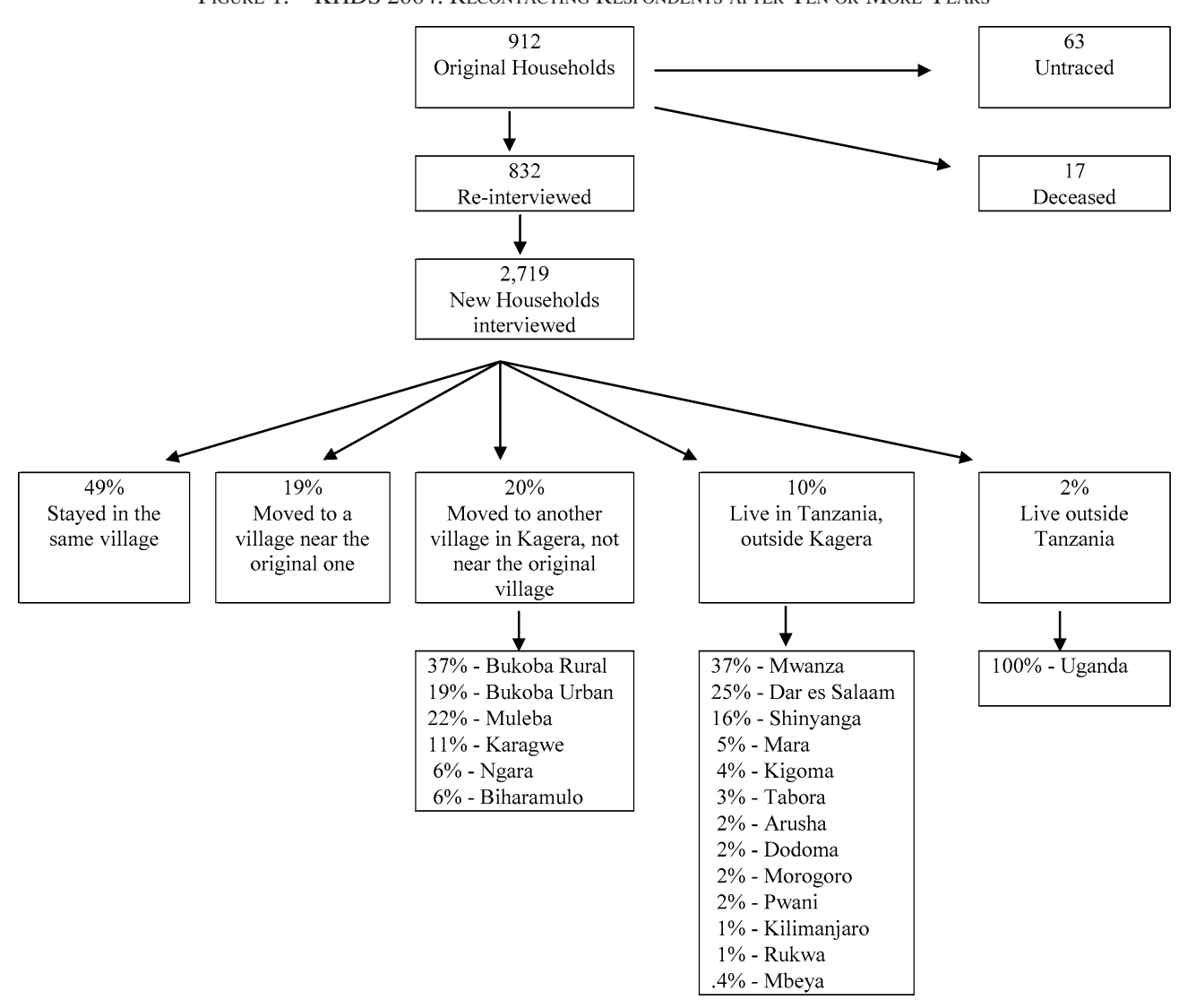

TABLE 1.-KHDS IndividuALS, By AGE

\begin{tabular}{|c|c|c|c|c|}
\hline $\begin{array}{l}\text { Age at Baseline, } \\
\text { 1991-1994 }\end{array}$ & Recontacted & Deceased & Untraced & $\begin{array}{l}\text { Reinterview Rate } \\
\text { among Survivors }\end{array}$ \\
\hline$<10$ years & $1,604(77.1 \%)$ & $160(7.7 \%)$ & $317(15.2 \%)$ & $83.5 \%$ \\
\hline $10-19$ years & $1,406(73.2 \%)$ & $104(5.4 \%)$ & $412(21.4 \%)$ & $77.3 \%$ \\
\hline 20-39 years & $823(63.3 \%)$ & $285(22.1 \%)$ & $190(14.6 \%)$ & $81.2 \%$ \\
\hline $40-59$ years & $436(70.6 \%)$ & $147(23.9 \%)$ & $34(5.5 \%)$ & $92.8 \%$ \\
\hline $60+$ years & $163(37.6 \%)$ & $262(60.4 \%)$ & $9(2.1 \%)$ & $94.8 \%$ \\
\hline Overall & $4,432(69.7 \%)$ & $958(15.1 \%)$ & $962(15.1 \%)$ & $82.2 \%$ \\
\hline
\end{tabular}

Sample of individuals ever interviewed in KHDS 1991-1994 and alive at last interview. Age categories are based on age at first interview.

TABLE 2.-KHDS REINTERVIEW RATES, By LOCATION

\begin{tabular}{lclr}
\hline \hline & Number & \multicolumn{1}{c}{ Location } & $\%$ \\
\hline Baseline sample & 6,352 & & \\
Reinterviewed & 4,432 & & 63.1 \\
& & Same community & 14.1 \\
& & Nearby community & 14.4 \\
& & Elsewhere in Kagera & 7.1 \\
& & Other region & 1.3 \\
Untraced & \multirow{2}{*}{962} & Other country & 56.6 \\
& & Kagera & 12.3 \\
& & Dar es Salaam & 10.4 \\
& & Mwanza & 7.9 \\
& & Other region & 5.5 \\
Deceased & & Other country & 7.3 \\
& & Don't know &
\end{tabular}

Location for untraced respondents is reported by other household members from the baseline survey who were successfully located, interviewed, and able to provide location information on the respondent. In some cases, this information comes from other relatives or neighbors residing in the baseline communities. chased food and nonfood expenditure. The nonfood component includes a range of nonfood purchases, as well as utilities, expenditure on clothing and other personal items, transfers out, and health expenditures. Funeral expenses and health expenses prior to the death of an ill person were excluded. Monetary levels were adjusted to account for spatial and temporal price differences, using price data collected in the Kagera survey in 1991 and 2004, and, for households outside Kagera, data from the National Household Budget Survey. Consumption is expressed in annual per capita terms. The poverty line is set at 109,663 Tanzanian shillings (TSh), calibrated to yield for our sample of respondents who remained in Kagera the same poverty rate as the 2000/01 National Household Budget Survey estimate for Kagera (29\%). At the time of the survey one U.S. dollar was worth around TSh 1,100. 
Table 3.-Average Consumption Movements of Panel Respondents, by 2004 Location

\begin{tabular}{|c|c|c|c|c|}
\hline & Mean 1991 & Mean 2004 & Difference in Means & $N$ \\
\hline \multicolumn{5}{|c|}{ Consumption poverty head count $(\%)$} \\
\hline Full sample & 0.34 & 0.27 & $-0.07 * * *$ & 4,116 \\
\hline Within community & 0.35 & 0.31 & $-0.03 * * *$ & 2,620 \\
\hline Nearby community & 0.33 & 0.21 & $-0.11 * * *$ & 577 \\
\hline Elsewhere in Kagera & 0.36 & 0.24 & $-0.12 * * *$ & 595 \\
\hline Out of Kagera & 0.30 & 0.07 & $-0.23 * * *$ & 324 \\
\hline \multicolumn{5}{|c|}{ Consumption per capita (TSh) } \\
\hline Full sample & 164,434 & 226,337 & $61,903 * * *$ & 4,116 \\
\hline Within community & 159,959 & 186,474 & $26,515 * * *$ & 2,620 \\
\hline Nearby community & 171,493 & 234,973 & $63,480 * * *$ & 577 \\
\hline Elsewhere in Kagera & 167,597 & 260,749 & $93,152 * * *$ & 595 \\
\hline Out of Kagera & 180,707 & 472,474 & $291,767 * * *$ & 324 \\
\hline \multicolumn{5}{|c|}{ Food consumption per capita (TSh) } \\
\hline Full sample & 106,805 & 146,701 & $39,896 * * *$ & 4,116 \\
\hline Within community & 104,184 & 121,725 & $17,541 * * *$ & 2,620 \\
\hline Nearby community & 111,207 & 152,624 & $41,417 * * *$ & 577 \\
\hline Elsewhere in Kagera & 108,763 & 166,379 & $57,616 * * *$ & 595 \\
\hline Out of Kagera & 115,704 & 303,453 & $187,749 * * *$ & 324 \\
\hline \multicolumn{5}{|c|}{ Nonfood consumption per capita (TSh) } \\
\hline Full sample & 57,629 & 79,636 & $22,007 * * *$ & 4,116 \\
\hline Within community & 55,775 & 64,748 & $8,973 * * *$ & 2,620 \\
\hline Nearby community & 60,286 & 82,348 & $22,062 * * *$ & 577 \\
\hline Elsewhere in Kagera & 58,834 & 94,369 & $35,535 * * *$ & 595 \\
\hline Out of Kagera & 65,003 & 169,021 & $107,018 * * *$ & 324 \\
\hline
\end{tabular}

Significance of the difference with the 1991 value using a paired $t$-test. $* 10 \%, * * 5 \%, * * * 1 \%$.

\section{Growth, Poverty, and Physical Mobility in Kagera}

In this section, we discuss changes in living standards overall and the changes for four mutually exclusive groups based on residence in 2004: (a) still residing in the baseline community, (b) residing in a neighboring community, (c) residing elsewhere in Kagera, and (d) residing outside Kagera.

Table 3 shows that the basic needs poverty rate declined 8 percentage points in the full sample. This figure masks significant differences in changes between subgroups based on migration. For those found residing in the baseline community, poverty rates dropped by 3 percentage points, but rates dropped by 11,12 , and 23 percentage points for those who moved to neighboring communities, elsewhere in Kagera, and outside Kagera, respectively. A similar pattern is found for consumption per capita. Although mean consumption per capita grew by TSh 61,903 overall, or $38 \%$, it grew by only $17 \%$ for those found in the same community and by $37 \%, 56 \%$, and $161 \%$ for those who moved to neighboring communities, elsewhere in Kagera, and outside Kagera, respectively. Dividing consumption into food and nonfood components gives the same result. The most basic assessment of welfare changes would have been wrong if we had focused only on individuals still residing in the community, a practice found in many panel data surveys. We would have underestimated the growth in consumption by half of its true increase.

For the groups in table 3, the differences in consumption changes are statistically significant, as shown in table 4. Excluding respondents who have relocated would omit those with greater rates of income growth and poverty reduction. Table 5 reports confidence intervals for the incre-
Table 4.-Differences in Consumption and Poverty Head Count Changes, By MOBILITy CATEgORIES

\begin{tabular}{|c|c|c|c|}
\hline & $N$ & $\begin{array}{l}\text { Average } \\
\text { Change }\end{array}$ & $\begin{array}{l}t \text {-Test for Equality } \\
\text { Change between } \\
\text { Both Subgroups }\end{array}$ \\
\hline \multicolumn{4}{|l|}{ Consumption per capita (TSh) } \\
\hline Stayed in community & 2,620 & 25,940 & $t=13.93$ \\
\hline Moved elsewhere & 1,496 & 120,534 & $p=0.0000$ \\
\hline $\begin{array}{l}\text { Stayed in same or } \\
\text { neighboring community }\end{array}$ & 3,197 & 31,432 & $t=16.67$ \\
\hline Moved elsewhere & 919 & 160,820 & $p=0.0000$ \\
\hline Stayed in Kagera & 3,792 & 41,460 & $t=20.25$ \\
\hline Moved elsewhere & 324 & 281,064 & $p=0.000$ \\
\hline \multicolumn{4}{|l|}{ Poverty head count (\%) } \\
\hline Stayed in community & 2,620 & -0.034 & $t=5.41$ \\
\hline Moved elsewhere & 1,496 & -0.140 & $p=0.000$ \\
\hline $\begin{array}{l}\text { Stayed in same or } \\
\text { neighboring community }\end{array}$ & 3,197 & -0.047 & $t=5.11$ \\
\hline Moved elsewhere & 919 & -0.162 & $p=0.000$ \\
\hline Stayed in Kagera & 3,792 & -0.059 & $t=4.94$ \\
\hline Moved elsewhere & 324 & -0.231 & $p=0.000$ \\
\hline
\end{tabular}

mental samples (which are not mutually exclusive); it gives a more detailed picture of how inference on consumption growth and poverty reduction would have changed if we had not tracked movers. It is apparent that inference from a "simple" panel survey of respondents continuing to reside within the original communities would have produced underestimates of actual consumption growth and poverty reduction in this population.

These conclusions are robust across the distribution of consumption, as well as at the mean and the poverty line. Panel A in figure 2 depicts the cumulative density function 
Table 5.-Sample Size, Mean, Standard Error, and 95\% Confidence Interval for Incremental Samples

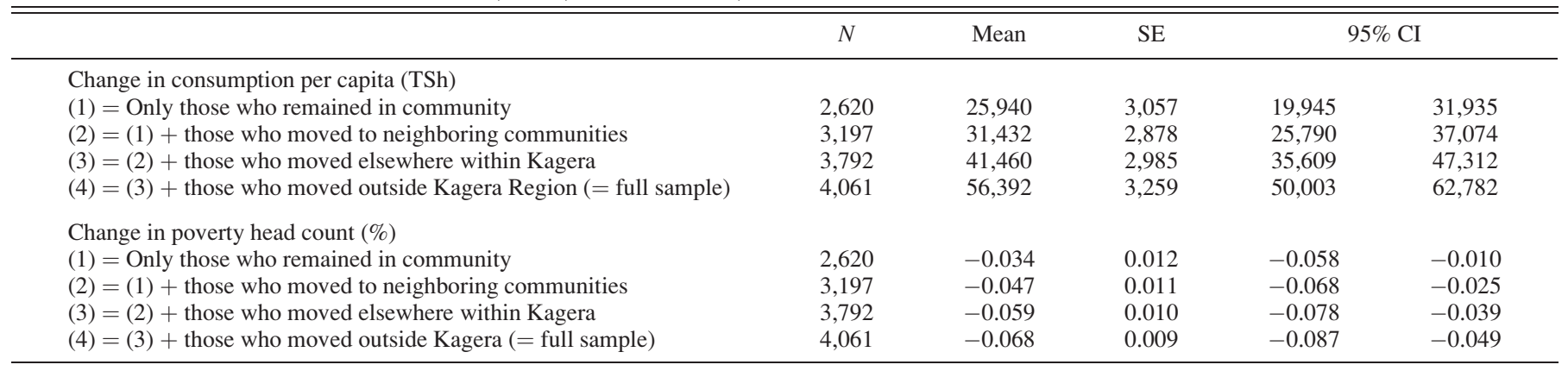

Figure 2.-Cumulative Density Functions of Consumption per Capita (Truncated at TSh 500,000)

PANEL A: Within Community $(N=2447)$

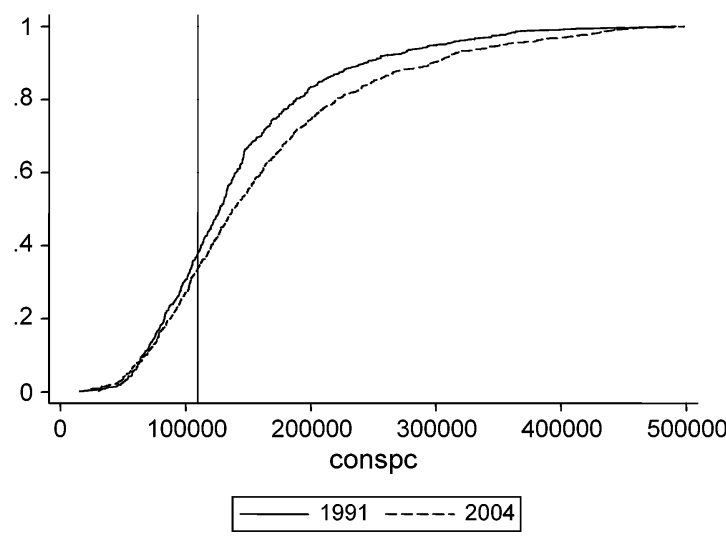

PANEL C: Elsewhere in Kagera $(N=489)$

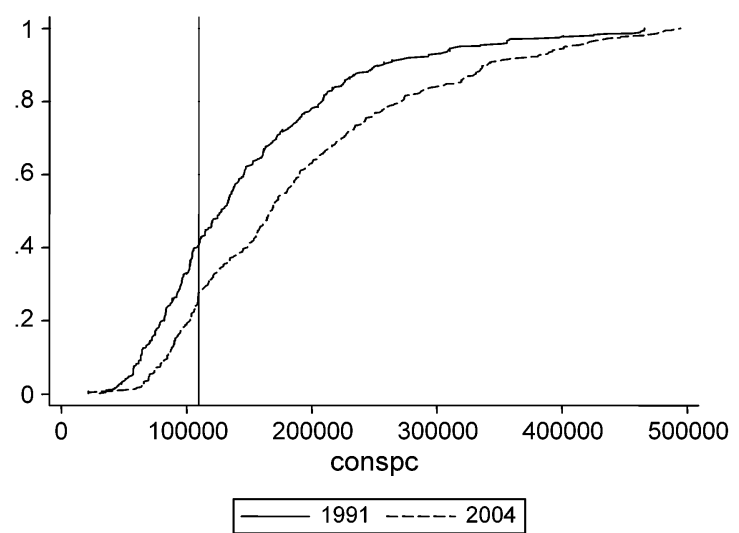

PANEL B: Near by Community $(N=509)$

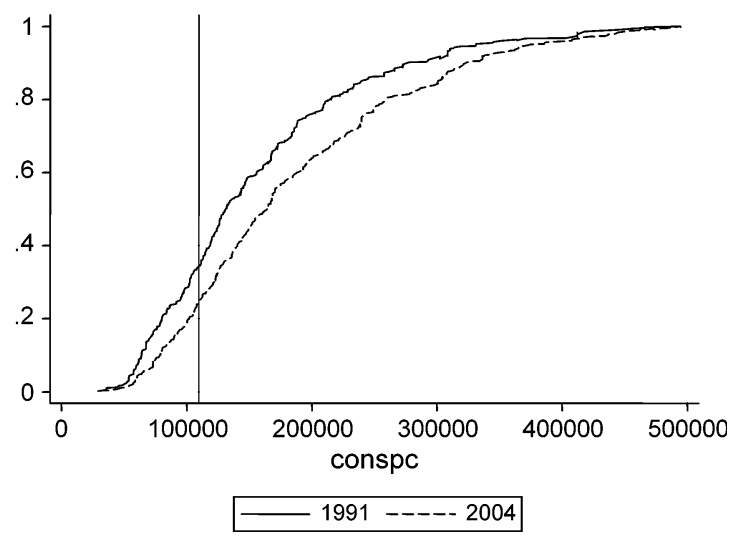

PANEL D: Outside Kagera $(N=221)$

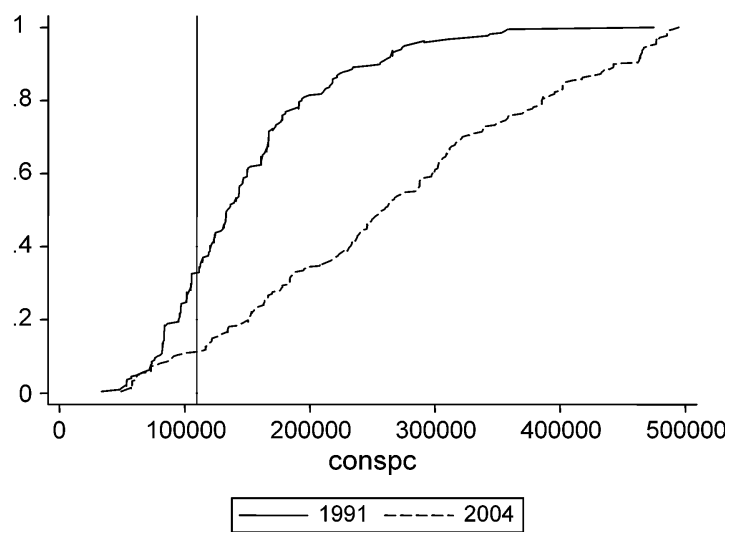

The vertical line is the basic needs poverty line (TSh 109,663).

for consumption per capita for those who remained in the same community. Panels B, C, and D show the cumulative density functions for respondents residing in neighboring communities, elsewhere in Kagera, and outside Kagera. For respondents who were located farther from their location in 1991, the differences between the functions for 1991 and 2004 are more pronounced. For people who remained in the baseline community, the 1991 and 2004 distributions lie close to each other under the poverty line and diverge above it; for the other mobility categories, there is greater divergence.

Figures 3, 4, and 5 offer another cut of the data, comparing consumption of nonmovers to movers in 1991 when both were living in the same community (panel A) and in 2004 (panel B). There is almost no difference between (future) nonmovers and movers in 1991, but by 2004, we 
Figure 3.-Cumulative Density Functions of Consumption per Capita within Community versus Nearby Community (Truncated at TSh 500,000)

PANEL A: 1991

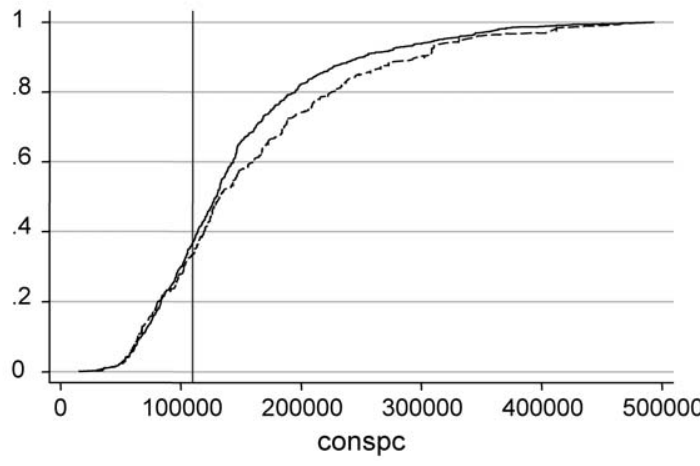

1991 in village ----- 1991 nearby village
PANEL B: 2004

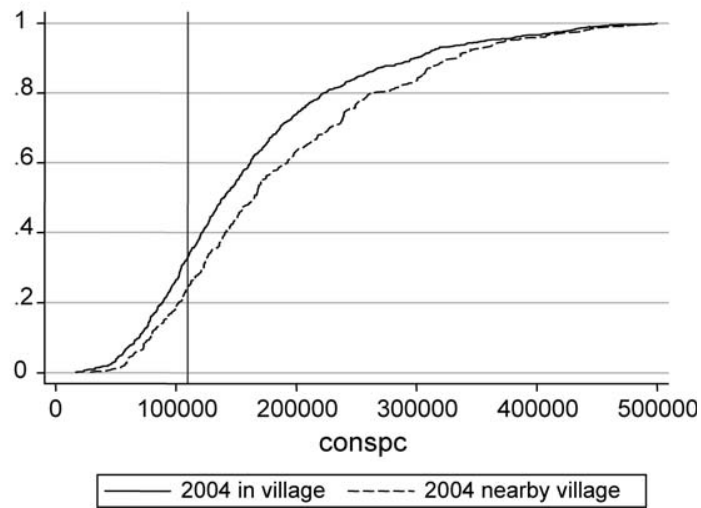

The vertical line is the basic needs poverty line (TSh 109,663).

Figure 4.-Cumulative Density Functions of Consumption per Capita within Community versus Elsewhere in Kagera (Truncated at TSh 500,000)

PANEL A: 1991

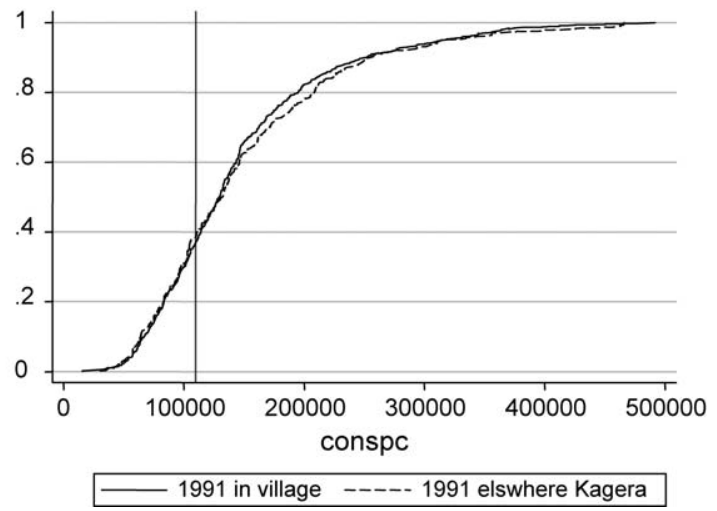

PANEL B: 2004

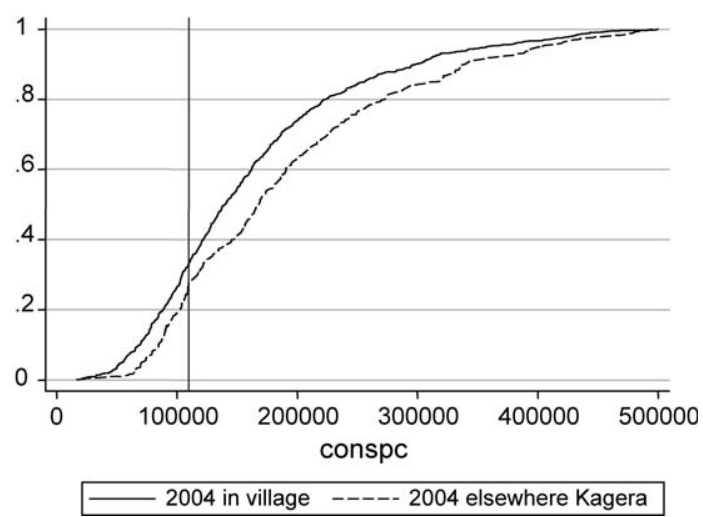

The vertical line is the basic needs poverty line (TSh 109,663).

Figure 5.-Cumulative Density Functions of Consumption per Capita within Community versus outside Kagera (Truncated at TSh 500,000)

PANEL A: 1991

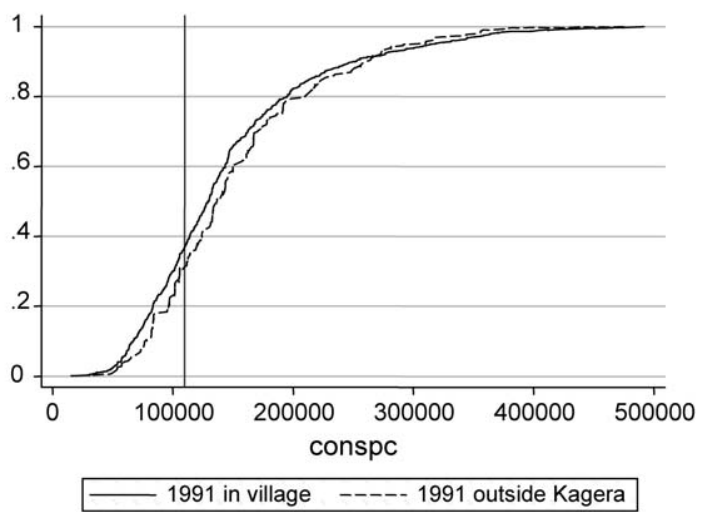

The vertical line is the basic needs poverty line (TSh 109,663).

observe divergent income levels. The divergence is greater between those who stayed and those who moved farther away (figures 4 and 5).
PANEL B: 2004

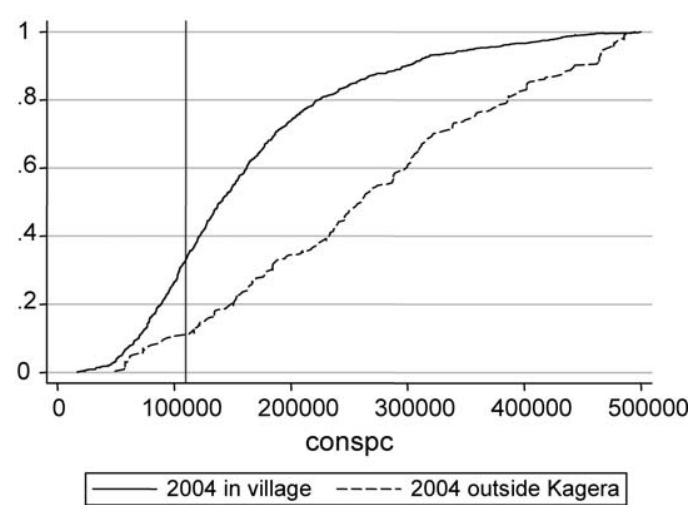

What drives the association between migration and income growth? One plausible explanation is that migrants are relocating to less remote, less poor areas. By 1991, 68\% 
Table 6.-Mean and Median Consumption Growth by Move to More oR Less Remote Area, 1991-2004

\begin{tabular}{lccc}
\hline \hline & Mean & Median & $N$ \\
\hline Did not move & 0.13 & 0.16 & 2,147 \\
Moved out of community & 0.53 & 0.50 & 1,080 \\
Out of those that moved out of community: & & & \\
$\quad$ Moved to more remote area & 0.28 & 0.21 & 380 \\
$\quad$ Moved to similar area & 0.46 & 0.45 & 378 \\
$\quad$ Moved to less remote area & 0.90 & 0.86 & 322 \\
\hline $\begin{array}{l}\text { Remoteness is based on the changes in classification among six possibilities: in order of remoteness, } \\
\text { island in Lake Victoria, remote village, connected village, urban center, district capital, and regional } \\
\text { capital. }\end{array}$
\end{tabular}

Table 7.-Mean and Median Consumption Growth by Sector Allocation Change, 1991-2004

\begin{tabular}{lrrr}
\hline \hline & Mean & Median & \multicolumn{1}{c}{$N$} \\
\hline Stay in agriculture & 0.21 & 0.22 & 1,721 \\
Move out of agriculture into nonagriculture & 0.69 & 0.67 & 408 \\
Stay in nonagriculture & 0.43 & 0.43 & 172 \\
Move into agriculture from nonagriculture & -0.05 & -0.03 & 245 \\
Total & 0.28 & 0.27 & 2,546 \\
\hline
\end{tabular}

of the sample was living in rural villages, of which a little more than half were categorized by the survey team as poorly connected in terms of infrastructure. The remainder of the sample were living in (or close to) the regional capital, Bukoba $(17 \%)$, or other small urban centers in Kagera (14\%). Table 6 investigates whether moving to a betterconnected center (for example, from a poorly connected to a better-connected village or from a rural area to an urban center) is correlated with higher consumption growth. ${ }^{3}$ This is indeed the case: about $10 \%$ of the sample moved to a better-connected area, and they experienced $90 \%$ consumption growth on average. For those who moved to a similar area, consumption increased by $46 \%$ on average, while those who moved to a less urban or less-connected center experienced a lower increase at $28 \%$. Clearly, it matters where people move, but moving in itself seems to matter too. ${ }^{4}$

Another plausible source of income growth for migrants is that they have moved to a different sector with respect to income. In table 7, we explore whether migration is correlated with change in occupation or sector. Consumption growth was highest for those who moved into nonagricul-

\footnotetext{
${ }^{3}$ Tables 6 and onward are restricted to the sample in the main regressions $(N=3,227)$. From the full sample of 4,432 , we exclude, in this order: 715 people who were not interviewed in wave 1 (they were interviewed in waves 2, 3, and/or 4), 15 people in one-person households, 267 people missing either wave 1 or wave 5 consumption expenditure, 120 people missing peer's schooling, 2 people missing parental education, and 86 people with incomplete data in wave 1 . Tables 7,8 , and 12 have 2,546 observations because of missing occupational data for 2004 .

${ }^{4}$ In order to investigate the clustering of migration patterns, all households were sorted into tracking zones, indicating the geographical area in which they resided in 2004. Tabulating, for each tracking zone, the village of origin of the households tracked in that zone did not reveal any discernable pattern of clustered migration. In each tracking zone, there was never any origin village that dominated, with the exception of villages that lie within or neighbor the tracking zone.
}

Table 8.-Mean Consumption Growth by Sector Allocation and Physical MoveMENT, 1991-2004

\begin{tabular}{cccc}
\hline \hline & $\begin{array}{c}\text { Stayed in } \\
\text { Community }\end{array}$ & $\begin{array}{c}\text { Moved out of } \\
\text { Community }\end{array}$ & All \\
\hline Stay in agriculture & 0.18 & 0.29 & 0.22 \\
Move out of agriculture & $(1,248)$ & $(473)$ & $(1,721)$ \\
into nonagriculture & 0.42 & 1.04 & 0.67 \\
Stay in nonagriculture & $(201)$ & $(207)$ & $(408)$ \\
& 0.11 & 0.88 & 0.44 \\
Move into agriculture & $(88)$ & $(84)$ & $(172)$ \\
from nonagriculture & $(157)$ & -0.00 & -0.03 \\
Total & 0.18 & $(88)$ & $(245)$ \\
& $(1,694)$ & 0.49 & 0.27 \\
& & $(852)$ & $(2,546)$ \\
\hline
\end{tabular}

ture $(67 \%)$, and there was considerable growth for those who started in nonagriculture. It is striking that the $10 \%$ who moved into agriculture from nonagriculture faced declining consumption, suggesting that this is a sign of hardship and possibly a means of coping with it. Table 8 reports consumption growth by both sector change and migration. A considerable number of people switched sectors without migrating but, within each category of sector status, migrants had much higher consumption growth than nonmigrants. The main source of income matters for consumption growth, but it is strongly related to migration as well. For example, those who moved out of agriculture while also moving out of their original community in this period more than doubled their consumption levels, while those who switched into agriculture while staying within the community faced a $12 \%$ reduction in consumption.

\section{Assessing the Impact of Migration on Consumption Outcomes}

The correlations above do not resolve whether this consumption growth is in fact directly related to migration or whether it is spurious. To investigate this further, we explore several empirical approaches. First, we employ a difference-in-difference estimator, comparing the consumption growth of those who moved with those who stayed in their baseline community. We define $\ln C_{i t}$ as the natural logarithm of consumption per capita for individual $i$ in period $t$, and $M_{i}$ as a dummy that is 1 if the individual was found to have physically moved out of the original community between $t$ and $t+1$, and 0 otherwise. The differencein-difference specification is

$$
\Delta \ln C_{i t+1, t}=\alpha+\beta M_{i}+\gamma X_{i t}+\delta_{i h}+\varepsilon_{i t},
$$

in which $\Delta \ln C_{i t+1, t}$ is $\left(\ln C_{i t+1}-\ln C_{i t}\right)$, the growth rate of consumption per capita in the household in which $i$ is residing in the two periods. This specification controls for individual fixed heterogeneity, which might have an impact on the level of consumption in each period. This resolves a large number of possible sources of endogeneity, such as risk aversion or ability, which are likely to affect both migration and income outcomes. However, it does not 
address concerns about heterogeneity among families or individuals affecting growth in consumption and the migration decision. For example, current wealth may affect the ability to migrate as well as the potential to grow between $t$ and $t+1$. McKenzie and Sasin (2007) discuss at length the issue of endogeneity with respect to measuring the impact of migration on poverty, stating that work that does not identify causal relations provides "rather weak grounds for policy recommendations." McKenzie et al. (2010) find that ignoring selection led to overstating the gains from migration from Tonga to New Zealand.

Our data, while not experimental, still offer excellent opportunities to control for a wide set of factors in this respect. First, we have data on multiple individuals from the original household, which allows us to control for any initial household-level heterogeneity $\left(\delta_{i h}\right)$ that may affect the growth of consumption by estimating equation (1) using initial household fixed effects (IHHFE). The result is that the impact of migration is identified using variation within the initial household: differences between members of the same initial household, effectively controlling for initial growth paths. Second, we can control for a set of individuallevel factors that may affect consumption growth, and possibly migration as well, by including these as $X_{i}$ in regression model (1). The variables used as individual conditioning variables for the growth of consumption from baseline are individual variables (sex, age, education relative to age-specific peer groups, ${ }^{5}$ and marital status) and family background variables (number of biological children in the initial household at baseline interacted with the agesex group of the children, the number of biological children living elsewhere interacted with the distance to the regional capital, and the years of education of the biological mother and father). We also include a variable indicating whether the individual lost both parents between 1991 and 2004, allowing a separate effect if the individual was below age 15 at baseline. Quite a few of these variables, such as educational level, marital status, parental death, or having children living elsewhere (offering opportunities for remit-

\footnotetext{
${ }^{5}$ We used the variable "years of schooling completed relative to peers" rather than a straight "years of schooling completed" for two reasons. First, a substantial number of individuals in the sample were younger than 18 at the baseline and therefore had not necessarily completed their education. As such, years of schooling at the baseline might be less correlated with a move by 2004 than, say, eventual completed years of schooling. Second, akin to this concern, years of schooling is highly correlated with age for individuals of school-going age. The regressions also include a set of age variables, defined in broad age groups (for ease of interpretation and discussion of results). One consequence could be that years of schooling at the baseline would pick up at least some age effect. To address this concern, rather than use education in years, we constructed a variable of education relative to peers: the absolute deviation of education levels compared with mean education of age-specific peers at the baseline for those younger than 18 and relative to other adults for the rest of the sample. This purges the education variable of an age effect it would otherwise pick up. All the regressions below were repeated using a straightforward "years of schooling" variable rather than our "years of schooling relative to peers" variable. Neither the results nor their interpretation were affected.
}

tances), are likely to affect migration, but also may have direct effects on consumption growth.

Despite controlling for fixed individual heterogeneity and both fixed and time-varying household-level heterogeneity (including initial growth paths) and the additional control variables, unobserved individual factors may still affect migration as well as consumption growth. We extend the analysis to 2SLS estimates, using three types of variables for instruments for the migration decision: pull factors, push factors, and variables reflecting social relationships.

The pull factors include age and baseline location. Migration opportunities and incentives are typically stronger for young male adults, as employment in low-skill and physically demanding activities is likely to be easier for them. Similarly, if a family were to decide who should migrate to capture opportunities, then allowing a young male adult to go would seem sensible. Costs and information needs for migration may well be affected by how far the opportunities are located. We include an interaction term of the distance to the regional capital and whether the person is male and between 5 and 15 years old at the baseline (so between 18 and 28 in 2004) as a measure of the opportunities available. ${ }^{6}$

Individuals may also be pushed into migration (or families may decide to send someone) when shocks occur. We include a measure of economic shocks experienced by the household by including a measure of negative rainfall shock. Using data from 21 weather stations in Kagera from 1980 to 2004, each of the 51 baseline villages was mapped to the nearest station, and 25-year average annual rainfall was computed. The largest deviation of rainfall between 1992 and 2002 from the long-run average was identified. This rainfall shock variable was interacted with being in the 5-to-15 age group as a measure of this push factor (with higher values defined as high-deviation rainfall).

Finally, norms and social circumstances are likely to affect migration. In particular, within a household, who is able or expected to migrate is likely to be determined by the individual's position in the household. We include indicators for being the head or spouse of the household head at the baseline. We expect these two positions in the household would make it less likely that the person would leave relative to others in the household. Age rank among those between 5 and 15 (with the oldest receiving the highest value) is also included. These indicators are unlikely to determine the consumption growth of the household, but may well affect whether a person is allowed, chosen, or chooses to migrate. Finally, close family members, the closest relatives of the household head, sons and daughters, may have different probabilities of leaving the household's community, compared with other residents, such as cousins or nephews. Local norms on marriage are patrilocal: girls

\footnotetext{
${ }^{6}$ The noninteracted variables are all included as determinants of consumption growth via $X_{i}$ and $\delta_{i h}$.
} 
are expected to move to the community of their husbands after marriage, and husbands are expected to stay where their father was based. We include an indicator for being the son of the household head at baseline. Although both sons and daughters of the head may be expected to be more likely to stay in the community than other initial household members, patrilocality would make this probability higher for boys than for girls.

In sum, this means we are using a set of six instruments. Although we will show in the appendix that statistically convincing and close to identical results are obtained by using subsets of these instruments, we focus on the full set of instruments in the discussion of the results.

Although our main measure of migration $\left(M_{i}\right)$ is an indicator for having moved, we also substitute this for the log of the distance moved (kilometers from the original community of the location in which the individual was found in 2004, "as the crow flies," set to 0 for nonmovers). We also extend the multivariate analysis to explore whether moving to a more urbanized area or changing employment sectors plays a role in increasing consumption growth.

\section{Regression Results}

Table 9 presents the basic results for the initial household fixed effects (IHHFE) and 2SLS estimates. (Table A1 presents the means and standard deviations for the covariates.) We estimate the regressions using an indicator for having moved and a measure of the distance of the move. The 2SLS estimates in columns 3 and 4 use the six instruments defined above. In table 10, we present the first-stage results of regressions explaining migration or the distance traveled in migration.

Before turning to the variables of interest, we briefly discuss the coefficients on the control variables. Recall that all effects are identified using variation within initial household. Those who are relatively better educated at baseline, relative to their peers and within the household, experienced much higher consumption growth, and the effect is strongly convex. Having an educated father has an additional effect on growth. The younger cohort did considerably better, as did males still unmarried at baseline.

Turning to the migration variables, we observe in the IHHFE regression a larger and statistically significant impact of migration on consumption growth. Moving out of the community resulted in a 36 percentage point increase in consumption growth over the thirteen-year period. As migrants move farther from their baseline community, the impact is greater. These effects are large, with migration resulting in a large divergence in income between people who initially lived together-usually parents, siblings, and other close relatives. Because this is the impact comparing within families, it nets out any transfers from migrants to nonmovers. That is, if migrants sent remittances back to their origin households, then the estimates in table 9 are a lower bound of the impact of moving (see also the results in the next section on alternative definitions of the consumption aggregate, excluding transfers out). It also seems counter to the theory that the migration decision is part of a household-level maximization strategy (although it cannot preclude that this is partly true).

For the first-stage results in table 10, in terms of basic diagnostics, our set of excluded instruments appears strong and valid: the Cragg-Donald $(F)$ test shows a value of 11.70 for the movement dummy and 9.07 for the distance regression. Especially in the former case, it is comfortably above the level of 10 often recommended for rejecting weak instruments (and in the latter case, still with relative limited bias in the tables in Stock \& Yogo, 2002). The results are also robust to exclusion of any of the instruments (see table A2).

Some interesting patterns explaining migration emerge from table 10. First, education offers strong and convex effects in leaving one's community. Being unmarried, especially being female and unmarried, is correlated with a higher probability of migration (consistent with patrilocality, whereby females move out of the paternal location at the time of marriage). When looking more specifically at the identifying instruments, we find significant effects, consistent with expectations: positional variables in the household matter, with the head and spouse less likely to leave, as are children of the head (relative to others belonging to the household). The effect is, however, considerably larger (more negative) for male children of the head-again consistent with patrilocality, as marriage norms make sons more likely to be expected to stay in the community than daughters. Older members among the children in the household are more likely to migrate, possibly reflecting some kind of pecking order, given the opportunities available. Rainfall shocks increase the probability of leaving. Finally, pull factors, like the interaction of being young, male, and residing close to the regional capital, increase the probability of leaving. The results are also consistent for the regressions with the dummy variable for migration and with the distance-migrated variable. In short, although not aiming to obtain a structural model, we find suggestive correlates for the process of migration from within households. These include better income opportunities (education and distance to the regional capital), norms of settlement and marriage, and other social factors.

The 2SLS results (IV with fixed effects) in columns 3 and 4 of table 9 are almost identical to the IHHFE results. They are slightly less statistically significant (as can be expected from IV regressions given their lower efficiency) but still significant at $5 \%$. Thus, there is no evidence that unobserved individual time-varying heterogeneity affects the noninstrumented results. For the distance variables, the results are marginally smaller (the coefficient is 0.10 compared with 0.12 ), suggesting limited evidence of a positive bias in the earlier results (migrants traveling longer distances are those with somewhat higher unobserved consumption growth potential, consistent with expectations). 
Table 9.-Explaining Consumption Change: IHHFE and 2SLS with IHHFE

\begin{tabular}{|c|c|c|c|c|}
\hline & $\begin{array}{c}(1) \\
\text { IHHFE }\end{array}$ & $\begin{array}{c}(2) \\
\text { IHHFE }\end{array}$ & $\begin{array}{c}(3) \\
\text { 2SLS with IHHFE }\end{array}$ & $\begin{array}{c}\text { (4) } \\
\text { 2SLS with IHHFE }\end{array}$ \\
\hline Moved outside community & $\begin{array}{l}0.363^{* * * *} \\
(0.025)\end{array}$ & & $\begin{array}{l}0.378 * * \\
(0.150)\end{array}$ & \\
\hline Kilometers moved (log of distance) & & $\begin{array}{l}0.120 * * * \\
(0.006)\end{array}$ & & $\begin{array}{l}0.104 * * \\
(0.043)\end{array}$ \\
\hline \multicolumn{5}{|l|}{ Individual characteristics at baseline } \\
\hline Deviation of years schooling from peers & $\begin{array}{l}0.013 * * \\
(0.006)\end{array}$ & $\begin{array}{c}0.009 \\
(0.006)\end{array}$ & $\begin{array}{l}0.013 * * \\
(0.006)\end{array}$ & $\begin{array}{c}0.010 \\
(0.006)\end{array}$ \\
\hline Squared deviation of years schooling from peers & $\begin{array}{l}0.004 * * * \\
(0.001)\end{array}$ & $\begin{array}{l}0.004 * * * \\
(0.001)\end{array}$ & $\begin{array}{l}0.004 * * * \\
(0.001)\end{array}$ & $\begin{array}{l}0.004 * * * \\
(0.001)\end{array}$ \\
\hline Male & $\begin{array}{r}-0.004 \\
(0.038)\end{array}$ & $\begin{array}{r}-0.009 \\
(0.037)\end{array}$ & $\begin{array}{c}-0.003 \\
(0.038)\end{array}$ & $\begin{array}{r}-0.010 \\
(0.037)\end{array}$ \\
\hline Unmarried & $\begin{array}{c}-0.023 \\
(0.056)\end{array}$ & $\begin{array}{r}-0.020 \\
(0.054)\end{array}$ & $\begin{array}{r}-0.027 \\
(0.064)\end{array}$ & $\begin{array}{c}-0.011 \\
(0.060)\end{array}$ \\
\hline Unmarried male & $\begin{array}{l}0.141 * * * \\
(0.045)\end{array}$ & $\begin{array}{l}0.131 * * * \\
(0.044)\end{array}$ & $\begin{array}{l}0.144 * * * \\
(0.053)\end{array}$ & $\begin{array}{l}0.123 * * \\
(0.049)\end{array}$ \\
\hline Both parents died & $\begin{array}{c}-0.006 \\
(0.084)\end{array}$ & $\begin{array}{l}0.013 \\
(0.081)\end{array}$ & $\begin{array}{r}-0.006 \\
(0.083)\end{array}$ & $\begin{array}{c}0.010 \\
(0.082)\end{array}$ \\
\hline Above 15 and both parents died & $\begin{array}{l}0.050 \\
(0.100)\end{array}$ & $\begin{array}{c}0.024 \\
(0.098)\end{array}$ & $\begin{array}{c}0.048 \\
(0.101)\end{array}$ & $\begin{array}{l}0.033 \\
(0.100)\end{array}$ \\
\hline Years of education mother & $\begin{array}{c}-0.003 \\
(0.006)\end{array}$ & $\begin{array}{c}-0.004 \\
(0.005)\end{array}$ & $\begin{array}{c}-0.003 \\
(0.006)\end{array}$ & $\begin{array}{c}-0.003 \\
(0.006)\end{array}$ \\
\hline Years of education father & $\begin{array}{l}0.008 * \\
(0.005)\end{array}$ & $\begin{array}{c}0.007 \\
(0.005)\end{array}$ & $\begin{array}{c}0.008 * \\
(0.005)\end{array}$ & $\begin{array}{c}0.007 \\
(0.005)\end{array}$ \\
\hline Biological children residing in household at baseline & & & & \\
\hline Male children $0-5$ & $\begin{array}{c}-0.028 \\
(0.031)\end{array}$ & $\begin{array}{r}-0.029 \\
(0.030)\end{array}$ & $\begin{array}{c}-0.028 \\
(0.030)\end{array}$ & $\begin{array}{c}-0.028 \\
(0.030)\end{array}$ \\
\hline Female children $0-5$ & $\begin{array}{r}-0.027 \\
(0.030)\end{array}$ & $\begin{array}{r}-0.024 \\
(0.029)\end{array}$ & $\begin{array}{r}-0.027 \\
(0.030)\end{array}$ & $\begin{array}{r}-0.025 \\
(0.029)\end{array}$ \\
\hline Male children 6-10 & $\begin{array}{c}0.009 \\
(0.035)\end{array}$ & $\begin{array}{c}0.014 \\
(0.034)\end{array}$ & $\begin{array}{c}0.009 \\
(0.035)\end{array}$ & $\begin{array}{c}0.014 \\
(0.034)\end{array}$ \\
\hline Female children $6-10$ & $\begin{array}{c}-0.045 \\
(0.038)\end{array}$ & $\begin{array}{c}-0.056 \\
(0.037)\end{array}$ & $\begin{array}{c}-0.046 \\
(0.037)\end{array}$ & $\begin{array}{c}-0.055 \\
(0.037)\end{array}$ \\
\hline Male children 11-15 & $\begin{array}{c}0.012 \\
(0.036)\end{array}$ & $\begin{array}{c}0.017 \\
(0.035)\end{array}$ & $\begin{array}{c}0.012 \\
(0.036)\end{array}$ & $\begin{array}{l}0.016 \\
(0.035)\end{array}$ \\
\hline Female children $11-15$ & $\begin{array}{r}-0.000 \\
(0.035)\end{array}$ & $\begin{array}{c}-0.006 \\
(0.034)\end{array}$ & $\begin{array}{c}-0.000 \\
(0.035)\end{array}$ & $\begin{array}{c}-0.007 \\
(0.034)\end{array}$ \\
\hline Male children 16-20 & $\begin{array}{c}0.010 \\
(0.041)\end{array}$ & $\begin{array}{c}0.001 \\
(0.040)\end{array}$ & $\begin{array}{c}0.010 \\
(0.041)\end{array}$ & $\begin{array}{c}0.001 \\
(0.040)\end{array}$ \\
\hline Female children $16-20$ & $\begin{array}{c}-0.085^{*} \\
(0.044)\end{array}$ & $\begin{array}{l}-0.093 * * \\
(0.043)\end{array}$ & $\begin{array}{r}-0.085^{*} \\
(0.044)\end{array}$ & $\begin{array}{l}-0.094 * * \\
(0.043)\end{array}$ \\
\hline Male children $21+$ & $\begin{array}{l}0.033 \\
(0.045)\end{array}$ & $\begin{array}{c}0.026 \\
(0.044)\end{array}$ & $\begin{array}{l}0.033 \\
(0.045)\end{array}$ & $\begin{array}{c}0.028 \\
(0.044)\end{array}$ \\
\hline Female children $21+$ & $\begin{array}{c}-0.073 \\
(0.055)\end{array}$ & $\begin{array}{c}-0.094 * \\
(0.054)\end{array}$ & $\begin{array}{c}-0.072 \\
(0.055)\end{array}$ & $\begin{array}{c}-0.094^{*} \\
(0.054)\end{array}$ \\
\hline Number of children residing outside household & $\begin{array}{c}-0.000 \\
(0.011)\end{array}$ & $\begin{array}{c}0.002 \\
(0.011)\end{array}$ & $\begin{array}{c}-0.000 \\
(0.011)\end{array}$ & $\begin{array}{c}0.001 \\
(0.011)\end{array}$ \\
\hline Kilometers from regional capital $\times$ number outside children & $\begin{array}{c}0.000 \\
(0.000)\end{array}$ & $\begin{array}{c}0.000 \\
(0.000)\end{array}$ & $\begin{array}{c}0.000 \\
(0.000)\end{array}$ & $\begin{array}{c}0.000 \\
(0.000)\end{array}$ \\
\hline Age at baseline (1991-1994) & & & & \\
\hline $5-15$ years & $\begin{array}{l}0.143 * * * \\
(0.030)\end{array}$ & $\begin{array}{l}0.139 * * * \\
(0.029)\end{array}$ & $\begin{array}{l}0.140 \text { *** } \\
(0.043)\end{array}$ & $\begin{array}{l}0.149 * * * \\
(0.040)\end{array}$ \\
\hline $16-25$ years & $\begin{array}{c}0.059 \\
(0.039)\end{array}$ & $\begin{array}{c}0.059 \\
(0.038)\end{array}$ & $\begin{array}{c}0.056 \\
(0.049)\end{array}$ & $\begin{array}{c}0.069 \\
(0.045)\end{array}$ \\
\hline $26-35$ years & $\begin{array}{l}0.108 * \\
(0.065)\end{array}$ & $\begin{array}{l}0.105^{*} \\
(0.063)\end{array}$ & $\begin{array}{l}0.107^{*} \\
(0.065)\end{array}$ & $\begin{array}{l}0.108 * \\
(0.063)\end{array}$ \\
\hline $36-45$ years & $\begin{array}{l}0.132 * \\
(0.080)\end{array}$ & $\begin{array}{c}0.130^{*} \\
(0.078)\end{array}$ & $\begin{array}{c}0.130 \\
(0.081)\end{array}$ & $\begin{array}{l}0.135^{*} \\
(0.079)\end{array}$ \\
\hline $46-55$ years & $\begin{array}{c}0.149 \\
(0.091)\end{array}$ & $\begin{array}{c}0.163 * \\
(0.088)\end{array}$ & $\begin{array}{c}0.148 \\
(0.090)\end{array}$ & $\begin{array}{c}0.164 * \\
(0.088)\end{array}$ \\
\hline $56-65$ years & $\begin{array}{c}0.118 \\
(0.098)\end{array}$ & $\begin{array}{c}0.123 \\
(0.096)\end{array}$ & $\begin{array}{c}0.118 \\
(0.098)\end{array}$ & $\begin{array}{c}0.124 \\
(0.095)\end{array}$ \\
\hline $66+$ years & $\begin{array}{c}0.180 \\
(0.121)\end{array}$ & $\begin{array}{c}0.168 \\
(0.118)\end{array}$ & $\begin{array}{c}0.179 \\
(0.120)\end{array}$ & $\begin{array}{c}0.172 \\
(0.118)\end{array}$ \\
\hline Constant & $\begin{array}{c}-0.023 \\
(0.064)\end{array}$ & $\begin{array}{c}-0.013 \\
(0.063)\end{array}$ & & \\
\hline Cragg-Donald & & & 11.86 & 9.33 \\
\hline Sargan statistic & & & 6.26 & 7.28 \\
\hline Sargan $p$-value & & & 0.28 & 0.20 \\
\hline Number of observations & 3,227 & 3,227 & 3,227 & 3,227 \\
\hline
\end{tabular}




\begin{tabular}{|c|c|c|}
\hline & $\begin{array}{c}(1) \\
\text { Moved }\end{array}$ & $\begin{array}{c}(2) \\
\text { Distance moved }\end{array}$ \\
\hline \multicolumn{3}{|l|}{ Baseline covariates: Excluded instruments } \\
\hline Head or spouse & $\begin{array}{l}-0.218 * * * \\
(0.038)\end{array}$ & $\begin{array}{l}-0.634 * * * \\
(0.147)\end{array}$ \\
\hline Child of head & $\begin{array}{l}-0.097 * * * \\
(0.032)\end{array}$ & $\begin{array}{l}-0.423 * * * \\
(0.123)\end{array}$ \\
\hline Male child of head & $\begin{array}{l}-0.114 * * * \\
(0.037)\end{array}$ & $\begin{array}{c}-0.334 * * \\
(0.144)\end{array}$ \\
\hline Age rank in household $\times$ age $5-15$ & $\begin{array}{l}14.390 * \\
(8.003)\end{array}$ & $\begin{array}{c}65.346^{*} \\
(30.884)\end{array}$ \\
\hline Kilometers from regional capital $\times$ male $\times$ age $5-15$ & $\begin{array}{l}-0.001 * * * \\
(0.000)\end{array}$ & $\begin{array}{l}-0.002 * * \\
(0.001)\end{array}$ \\
\hline Rainfall shock $\times$ age $5-15$ & $\begin{array}{l}0.002 * * \\
(0.001)\end{array}$ & $\begin{array}{l}0.007 * * \\
(0.003)\end{array}$ \\
\hline \multicolumn{3}{|l|}{ Individual characteristics at baseline } \\
\hline Deviation of years schooling from peers & $\begin{array}{l}0.012 * * \\
(0.005)\end{array}$ & $\begin{array}{l}0.071^{* * * *} \\
(0.018)\end{array}$ \\
\hline Squared deviation of years schooling from peers & $\begin{array}{l}0.003 * * \\
(0.001)\end{array}$ & $\begin{array}{l}0.014 * * * \\
(0.004)\end{array}$ \\
\hline Male & $\begin{array}{c}-0.017 \\
(0.030)\end{array}$ & $\begin{array}{c}-0.010 \\
(0.116)\end{array}$ \\
\hline Unmarried & $\begin{array}{l}0.137 * * * \\
(0.048)\end{array}$ & $\begin{array}{l}0.464 * * \\
(0.187)\end{array}$ \\
\hline Unmarried male & $\begin{array}{c}-0.105^{* *} \\
(0.042)\end{array}$ & $\begin{array}{c}-0.244 \\
(0.164)\end{array}$ \\
\hline Both parents died & $\begin{array}{r}-0.029 \\
(0.066)\end{array}$ & $\begin{array}{c}-0.261 \\
(0.253)\end{array}$ \\
\hline Above 15 and both parents died & $\begin{array}{c}0.113 \\
(0.079)\end{array}$ & $\begin{array}{l}0.562 * \\
(0.304)\end{array}$ \\
\hline Years of education mother & $\begin{array}{l}0.012 * * * \\
(0.004)\end{array}$ & $\begin{array}{l}0.040 * * \\
(0.017)\end{array}$ \\
\hline Years of education father & $\begin{array}{l}-0.002 \\
(0.004)\end{array}$ & $\begin{array}{r}-0.000 \\
(0.015)\end{array}$ \\
\hline \multicolumn{3}{|l|}{ Biological children residing in houshold at baseline } \\
\hline Male children $0-5$ & $\begin{array}{c}-0.001 \\
(0.024)\end{array}$ & $\begin{array}{c}0.008 \\
(0.093)\end{array}$ \\
\hline Female children $0-5$ & $\begin{array}{c}-0.001 \\
(0.024)\end{array}$ & $\begin{array}{c}-0.010 \\
(0.092)\end{array}$ \\
\hline Male children 6-10 & $\begin{array}{c}-0.001 \\
(0.028)\end{array}$ & $\begin{array}{r}-0.059 \\
(0.107)\end{array}$ \\
\hline Female children 6-10 & $\begin{array}{c}-0.006 \\
(0.030)\end{array}$ & $\begin{array}{c}0.038 \\
(0.116)\end{array}$ \\
\hline Male children $11-15$ & $\begin{array}{c}-0.011 \\
(0.028)\end{array}$ & $\begin{array}{c}-0.083 \\
(0.110)\end{array}$ \\
\hline Female children $11-15$ & $\begin{array}{r}-0.035 \\
(0.027)\end{array}$ & $\begin{array}{c}-0.077 \\
(0.105)\end{array}$ \\
\hline Male children 16-20 & $\begin{array}{r}-0.022 \\
(0.032)\end{array}$ & $\begin{array}{c}-0.006 \\
(0.125)\end{array}$ \\
\hline Female children 16-20 & $\begin{array}{c}-0.031 \\
(0.035)\end{array}$ & $\begin{array}{r}-0.036 \\
(0.134)\end{array}$ \\
\hline Male children $21+$ & $\begin{array}{c}0.020 \\
(0.036)\end{array}$ & $\begin{array}{c}0.127 \\
(0.137)\end{array}$ \\
\hline Female children $21+$ & $\begin{array}{c}-0.016 \\
(0.044)\end{array}$ & $\begin{array}{c}0.127 \\
(0.169)\end{array}$ \\
\hline Number of children residing outside household & $\begin{array}{c}-0.008 \\
(0.009)\end{array}$ & $\begin{array}{c}-0.043 \\
(0.033)\end{array}$ \\
\hline Kilometers from regional capital $\times$ number outside children & $\begin{array}{l}0.000^{* *} \\
(0.000)\end{array}$ & $\begin{array}{l}0.001 * * \\
(0.000)\end{array}$ \\
\hline \multicolumn{3}{|l|}{ Age at baseline (1991-1994) } \\
\hline $5-15$ years & $\begin{array}{l}0.284 * * * \\
(0.054)\end{array}$ & $\begin{array}{l}0.886^{* * * *} \\
(0.210)\end{array}$ \\
\hline $16-25$ years & $\begin{array}{l}0.206^{* * * *} \\
(0.031)\end{array}$ & $\begin{array}{l}0.603 * * * \\
(0.118)\end{array}$ \\
\hline $26-35$ years & $\begin{array}{l}0.079 \\
(0.051)\end{array}$ & $\begin{array}{l}0.246 \\
(0.198)\end{array}$ \\
\hline $36-45$ years & $\begin{array}{l}0.135^{* *} * \\
(0.063)\end{array}$ & $\begin{array}{c}0.403 * \\
(0.243)\end{array}$ \\
\hline $46-55$ years & $\begin{array}{c}0.079 \\
(0.071)\end{array}$ & $\begin{array}{c}0.095 \\
(0.276)\end{array}$ \\
\hline $56-65$ years & $\begin{array}{c}0.046 \\
(0.078)\end{array}$ & $\begin{array}{c}0.068 \\
(0.300)\end{array}$ \\
\hline $66+$ years & $\begin{array}{c}0.056 \\
(0.095)\end{array}$ & $\begin{array}{c}0.246 \\
(0.366)\end{array}$ \\
\hline Number of observations & 3,227 & 3,227 \\
\hline
\end{tabular}

Standard errors are in parentheses. Significance at $* * * 1 \%, * * 5 \%, * 10 \%$. Linear probability model (column 1) and OLS (column 2 ) with household fixed effects. 
Still, the difference is remarkably small. The conclusion is strong: being able to move out of the village or community appears to be an important factor for consumption growth. If those who moved had stayed behind, our evidence suggests that they would not have done as well.

The fact that there is little change going from the IHHFE to the 2SLS results does not suggest that there is no selection process in the migration decision. For example, it could be expected that more able people migrate. There is some evidence that this occurs, yet this heterogeneity is not at the individual level but at the household level. Estimating the 2SLS without IHHFE increases the coefficient on migrant status by almost a third (from 0.37 to 0.57 ). This is consistent with the proposition of positive selection among households: individuals from households with high earning potential migrate. Within the household, there seems to be no unobserved heterogeneity in terms of earning potential among those who do or do not migrate.

These results are not driven by the lack of a parsimonious set of instruments or relatively weak instruments. The results are similar when restricting the instrument set. When focusing only on the relational variables (head, spouse, son, daughter), the Cragg-Donald $(F)$ statistics become 14.5 and 11.3 , the Sargan is not rejected, the coefficient on physical movement stays at 0.36 , and the distance variable becomes 0.097 , virtually identical to the results in table 9 .

The validity of our interacted instruments assumes that they do not capture different growth rates (for example, because of different labor markets) across these groups within households. Although growth rates might be influenced by the distance to the regional capital, rainfall shocks, gender, age, and other characteristics, additively, there is no evidence to suggest that the interaction of these would capture different growth rates outside the migration effect. To explore this point, we exploit the fact that the 1991-1994 baseline data consist of four waves. The wave 1 data were used as the baseline for this paper because the consumption recall period was identical to the follow-up survey (wave 5). We use the three interim waves (2-4), which have similar recall periods, to check the validity of our interacted instruments. Using a measure of annual consumption per capita growth for 1992-1993, we can check whether our instruments, appropriately defined for this period, jointly or individually explain the baseline consumption changes. We find that they do not, giving further confidence that the exclusion restriction is valid for our instruments: the instruments do not influence growth except through migration. Of course, this regression of baseline growth rates on our instruments can be valid only if migration can be plausibly omitted from it. We do find that 1992 was the year with the lowest and 1993 the third-lowest migration rates of all the years between 1992 and 2004, suggesting that the omission of the migration variable from the regression should not to lead to specification errors. As can be expected, the same exercise for the regressions in table 9, with the endogenous moved variable replaced directly by the instruments, does yield jointly significant instruments (at 10\%).

\section{Robustness}

We perform a variety of checks to verify the robustness of the findings. First, we use alternative definitions of the consumption aggregate, in particular excluding transfers out, which could be an important driver of our results if remittances to one's origin village are large. We have data on transfers sent between the 2004 households of the same origin. The size of these remittances is on average only a small percentage of total consumption. Our findings are robust to excluding this component.

Second, we check the role of the configuration of the data. Our outcomes are household-level measures of consumption per capita in levels and growth, assigned to individuals. We re-structure the data to the 2004 household level in tables A3 and A4 (using average characteristics as controls and appropriately defined household-level aggregated instruments). The results are similar and consistent regardless, of analyzing the data at the individual or household level.

Third, concerns may be raised that changes in household size and composition in new households in 2004 are driving the results. Table A5 shows that migrant households are smaller in terms of members or adult-equivalent members. Table A6 repeats the analysis using adult-equivalent units rather than household size as the denominator and finds essentially similar results

Fourth, we investigate whether lack of common support drives the results. The coefficients in the IHHFE regressions are identified from the sample households that had split up from the baseline. Restricting the sample to the 2,940 individuals from at least two split-offs in 2004 yields identical results in both the IHHFE and 2SLS estimations. We further refine this by examining the sample of individuals from origin households that split off into at least one household that moved by $2004(N=2,520)$ and the sample of individuals from origin households that had at least one split-off that remained in the village $(N=2,777)$. These samples yield identical results for both IHHFE and 2SLS. Restricting the sample further to baseline households that had at least one split-off that moved and one that remained in the village $(N=2,357)$ yields identical IHHFE results, but has 2SLS estimates of 0.23 and 0.68 for the migration indicator variable and distance variables, significant at $10 \%$ and $7 \%$, respectively, and with IV diagnostics that remain sound. Taken together, these sample restrictions do not cast doubt on the validity of the results, although they suggest that the size of the effects may be slightly lower than indicated in table 9.

As an alternative to the fixed-effects model and the twostage estimation, we investigate a number of matching models. Of course, the advantage of matching techniques is that they ensure comparison of like-with-like, with less 
Table 11.-Explaining Consumption Change: IHHFE, with Change in Schooling and Interactions

\begin{tabular}{|c|c|c|c|c|}
\hline & $\begin{array}{c}(1) \\
\text { IHHFE } \\
\text { Coefficient/se }\end{array}$ & $\begin{array}{c}(2) \\
\text { IHHFE } \\
\text { Coefficient/se }\end{array}$ & $\begin{array}{c}(3) \\
\text { IHHFE } \\
\text { Coefficient/se }\end{array}$ & $\begin{array}{c}(4) \\
\text { IHHFE } \\
\text { Coefficient/se }\end{array}$ \\
\hline Moved outside community & $\begin{array}{l}0.364 * * * \\
(0.025)\end{array}$ & & $\begin{array}{l}0.262 * * * \\
(0.033)\end{array}$ & \\
\hline Kilometers moved & & $\begin{array}{l}0.120 * * * \\
(0.006)\end{array}$ & & $\begin{array}{l}0.099 * * * \\
(0.009)\end{array}$ \\
\hline Gains in years of education & $\begin{array}{l}0.018^{* * *} \\
(0.005)\end{array}$ & $\begin{array}{l}0.018^{* * *} \\
(0.005)\end{array}$ & $\begin{array}{l}0.005 \\
(0.006)\end{array}$ & $\begin{array}{c}0.010^{*} \\
(0.005)\end{array}$ \\
\hline Gains in education $\times$ moved dummy & & & $\begin{array}{l}0.033 * * * \\
(0.007)\end{array}$ & \\
\hline Gains in education $\times$ kilometers moved & & & & $\begin{array}{l}0.006^{* * * *} \\
(0.002)\end{array}$ \\
\hline Deviation of years schooling from peers & $\begin{array}{l}0.017 \text { *** } \\
(0.006)\end{array}$ & $\begin{array}{l}0.013 * * \\
(0.006)\end{array}$ & $\begin{array}{l}0.018 * * * \\
(0.006)\end{array}$ & $\begin{array}{l}0.014 * * \\
(0.006)\end{array}$ \\
\hline Squared deviation of years schooling from peers & $\begin{array}{l}0.005^{* * * *} \\
(0.001)\end{array}$ & $\begin{array}{l}0.004 * * * \\
(0.001)\end{array}$ & $\begin{array}{l}0.005^{* * * *} \\
(0.001)\end{array}$ & $\begin{array}{l}0.004 * * * \\
(0.001)\end{array}$ \\
\hline Number of observations & 3,226 & 3,226 & 3,226 & 3,226 \\
\hline
\end{tabular}

restrictive functional form assumptions and omission of noncomparable observations. The disadvantage is that they ignore potential unobservables (such as ability) that drive selection into migration. Across an array of different matching techniques (Gaussian, nearest neighbor, Epanechnikov), the main findings on the impact of migration on consumption gains are remarkably robust to the results in table 10 (results not presented).

Finally, we examine the role of time-varying factors, specifically education. If migration itself is the result of the individual's efforts to increase his or her level of education, we might be capturing the gains to a migration-education bundle rather than to migration per se. For secondary schooling, often in the form of boarding schools in Tanzania, this is a plausible concern. At the primary level, few people migrate for schooling opportunities, and tertiary education is limited for this sample. Descriptively, we find that the likelihood of a move is not correlated with additional grades of schooling conditional on age, suggesting that the moves we observe are not specifically driven by demand for education. Exploring this further, we repeated the regressions in table 9 but this time included the years of education gained between rounds, as well as the interaction of schooling gains with the migration variables. We have to be cautious in interpreting these results, as surely migrating between rounds and years of education gained between rounds are bound to be joint decisions. Nevertheless, the results can at least explore whether the observed premium is just driven by education gains. Table 11 shows the results (only reporting the migration and education variables, but the independent variables are otherwise identical to those in table 9). ${ }^{7}$ Our findings are robust to including education gains. The results in columns 1

\footnotetext{
${ }^{7}$ Only the IHHFE and not the 2SLS results are reported here. When estimating the first column using 2SLS with the same instruments as before, but also including the education gained in the first and second stages, gave close to identical results as the IHHFE regressions (not shown). In the first-stage regression, the variable additional years of education gained is not correlated with the likelihood of moving, conditional on age.
}

and 2 indicate that even controlling for educational gains, the premium remains high and virtually identical to the earlier results. Including the interaction terms in columns 3 and 4 shows nevertheless that some of the gains may well work through education: the returns to moves are higher for those who added more years of schooling, although for those without additional schooling since the baseline, the returns to movement are still considerable.

\section{Migration Incentives, Social Constraints, and Windows of Opportunity}

The regressions in tables 9 and 10 are suggestive of how the relatively traditional and tightly knit society of Kagera reacted to growing economic opportunities in the past decade. There is substantial movement out of these communities, and those moving capture a substantial premium when measured in consumption terms. At the same time, the high premium may indicate opportunities that have not been taken.

In this section, we build a narrative around these results in four steps. First, we argue that there are windows of opportunity that arise over time and space in the region, and people need to move in order to take advantage of these opportunities. Second, we complete the discussion of the drivers of migration; the regressions in table 10 used household fixed effects and therefore do not reveal correlates of the constraints to migration at the household and community levels. Third, we discuss how social norms can prevent some people from moving. Finally, we argue why such welfare-reducing constraints may be imposed by society on its members, thus providing a potential answer to the question of why more people do not move if the payoffs are so high. At the end of this section, we discuss what our results imply in terms of standard models of migration and qualify this discussion by offering a few alternatives that cannot be rejected given the data available.

The economic landscape in the Kagera region, as in other regions in Africa, has been changing in the past two decades. 
Table 12-Explaining Consumption Change: IHHFE, Characteristics OF THE Move

\begin{tabular}{|c|c|c|}
\hline & $\begin{array}{c}(1) \\
\text { IHHFE }\end{array}$ & $\begin{array}{l}(2) \\
\text { IHHFE }\end{array}$ \\
\hline \multicolumn{3}{|l|}{ Characteristics of the move } \\
\hline Move to more remote area & $\begin{array}{l}0.176^{* * *} \\
(0.036)\end{array}$ & \\
\hline Move to similar area & $\begin{array}{l}0.274 * * * \\
(0.034)\end{array}$ & \\
\hline Move to more connected area & $\begin{array}{l}0.661 * * * \\
(0.037)\end{array}$ & \\
\hline Kilometers moved & & $\begin{array}{l}0.073 * * * \\
(0.011)\end{array}$ \\
\hline Distance moved if to similar area & & $\begin{array}{l}0.032 * * \\
(0.015)\end{array}$ \\
\hline Distance moved if to more connected area & & $\begin{array}{l}0.070 * * * \\
(0.013)\end{array}$ \\
\hline \multicolumn{3}{|l|}{ Individual characteristics at baseline } \\
\hline Deviation of years schooling from peers & $\begin{array}{l}0.010^{*} \\
(0.006)\end{array}$ & $\begin{array}{l}0.008 \\
(0.006)\end{array}$ \\
\hline $\begin{array}{l}\text { Squared deviation of years } \\
\text { schooling from peers }\end{array}$ & $\begin{array}{l}0.004 * * * \\
(0.001)\end{array}$ & $\begin{array}{l}0.004 * * * \\
(0.001)\end{array}$ \\
\hline Male & $\begin{array}{c}-0.004 \\
(0.037)\end{array}$ & $\begin{array}{r}-0.008 \\
(0.037)\end{array}$ \\
\hline Unmarried & $\begin{array}{c}-0.008 \\
(0.054)\end{array}$ & $\begin{array}{r}-0.006 \\
(0.054)\end{array}$ \\
\hline Unmarried male & $\begin{array}{l}0.127 * * * \\
(0.044)\end{array}$ & $\begin{array}{l}0.121 * * * \\
(0.043)\end{array}$ \\
\hline Both parents died & $\begin{array}{c}0.005 \\
(0.082)\end{array}$ & $\begin{array}{c}0.025 \\
(0.081)\end{array}$ \\
\hline Above 15 and both parents died & $\begin{array}{c}0.053 \\
(0.098)\end{array}$ & $\begin{array}{c}0.020 \\
(0.097)\end{array}$ \\
\hline Years of education mother & $\begin{array}{r}-0.004 \\
(0.005)\end{array}$ & $\begin{array}{r}-0.004 \\
(0.005)\end{array}$ \\
\hline Years of education father & $\begin{array}{c}0.006 \\
(0.005)\end{array}$ & $\begin{array}{c}0.006 \\
(0.005)\end{array}$ \\
\hline \multicolumn{3}{|c|}{ Biological children residing in household at baseline } \\
\hline Male children $0-5$ & $\begin{array}{r}-0.021 \\
(0.030)\end{array}$ & $\begin{array}{c}-0.023 \\
(0.030)\end{array}$ \\
\hline Female children $0-5$ & $\begin{array}{r}-0.026 \\
(0.029)\end{array}$ & $\begin{array}{r}-0.025 \\
(0.029)\end{array}$ \\
\hline Male children 6-10 & $\begin{array}{c}0.008 \\
(0.034)\end{array}$ & $\begin{array}{c}0.015 \\
(0.034)\end{array}$ \\
\hline Female children $6-10$ & $\begin{array}{c}-0.048 \\
(0.037)\end{array}$ & $\begin{array}{r}-0.056 \\
(0.036)\end{array}$ \\
\hline Male children 11-15 & $\begin{array}{c}0.023 \\
(0.035)\end{array}$ & $\begin{array}{c}0.022 \\
(0.035)\end{array}$ \\
\hline Female children $11-15$ & $\begin{array}{r}-0.010 \\
(0.034)\end{array}$ & $\begin{array}{r}-0.011 \\
(0.033)\end{array}$ \\
\hline Male children 16-20 & $\begin{array}{c}0.012 \\
(0.040)\end{array}$ & $\begin{array}{c}0.002 \\
(0.040)\end{array}$ \\
\hline Female children 16-20 & $\begin{array}{c}-0.085^{*} \\
(0.043)\end{array}$ & $\begin{array}{l}-0.095^{* *} \\
(0.043)\end{array}$ \\
\hline Male children $21+$ & $\begin{array}{c}0.023 \\
(0.044)\end{array}$ & $\begin{array}{c}0.020 \\
(0.044)\end{array}$ \\
\hline Female children $21+$ & $\begin{array}{c}-0.090^{*} \\
(0.054)\end{array}$ & $\begin{array}{r}-0.099^{*} \\
(0.054)\end{array}$ \\
\hline $\begin{array}{l}\text { Number of children residing } \\
\text { outside household }\end{array}$ & $\begin{array}{r}-0.001 \\
(0.011)\end{array}$ & $\begin{array}{c}0.003 \\
(0.011)\end{array}$ \\
\hline $\begin{array}{l}\text { Kilometers from regional capital } \times \\
\text { number outside children }\end{array}$ & $\begin{array}{c}0.000 \\
(0.000)\end{array}$ & $\begin{array}{c}0.000 \\
(0.000)\end{array}$ \\
\hline Age at baseline (1991-1994) & & \\
\hline $5-15$ years & $\begin{array}{l}0.141 * * * \\
(0.029)\end{array}$ & $\begin{array}{l}0.143 * * * \\
(0.028)\end{array}$ \\
\hline $16-25$ years & $\begin{array}{l}0.063 * \\
(0.038)\end{array}$ & $\begin{array}{c}0.066^{*} \\
(0.038)\end{array}$ \\
\hline $26-35$ years & $\begin{array}{l}0.107 * \\
(0.063)\end{array}$ & $\begin{array}{c}0.102 \\
(0.063)\end{array}$ \\
\hline $36-45$ years & $\begin{array}{l}0.130 * \\
(0.078)\end{array}$ & $\begin{array}{l}0.131 * \\
(0.077)\end{array}$ \\
\hline $46-55$ years & $\begin{array}{c}0.164 * \\
(0.088)\end{array}$ & $\begin{array}{l}0.166^{*} \\
(0.088)\end{array}$ \\
\hline
\end{tabular}

\begin{tabular}{ccc}
\multicolumn{3}{c}{ TABle 12.-(CONTINUED) } \\
\hline \hline & $(1)$ & $(2)$ \\
& IHHFE & IHHFE \\
\hline $56-65$ years & 0.135 & 0.127 \\
& $(0.096)$ & $(0.095)$ \\
$66+$ years & 0.190 & 0.169 \\
& $(0.118)$ & $(0.117)$ \\
Constant & -0.015 & -0.007 \\
\multirow{2}{*}{ Number of observations } & $(0.063)$ & $(0.062)$ \\
& 3,227 & 3,227 \\
\hline Standard errors are in parentheses. Significance at $* * * 1 \%, * * 5 \%, * 10 \%$.
\end{tabular}

Growth opportunities are continually being introduced and eliminated across time and space, as the refugee crisis abates, links with war-ridden bordering countries change, and more localized negative and positive shocks manifest themselves with various degrees of severity. People need to be physically (geographically) mobile in order to respond to the opportunities. To elaborate on this point, we decompose the results of table 9 further to examine the role of the location of a move (more or less remote areas) and moves associated with sector changes (out of agriculture into nonagricultural activities). Table 12 disaggregates the migration variable into three categories of migration (moving to a more or less connected or urbanized area). Even moving to a less connected area is still correlated with higher growth compared with not moving, but moving to a more connected area results in consumption growth that is 66 percentage points higher than not moving. The same result is found using the distance of the move in the second column. Although where individuals move matters for the magnitude of the effect, any movement has the potential to be welfare improving.

In table 13, we interact migration with change in sector (out of agriculture). We pool people who moved out of agriculture and those who remained in nonagriculture. Both groups had statistically indistinguishable findings in all regressions. The first column shows that moving out of agriculture is strongly linked to higher consumption growth (as noted above in the descriptive statistics). The next two columns show a large and positive impact of moving, even after controlling sector shifts; there is also a strong interactive effect of this sector shift with physical movement out of the village. In other words, it is not just the move out of agriculture that accounts for the large growth differential; migration as physical movement out of the village has strong additional and complementary effects.

Tables 12 and 13 thus show that movement in itself is important. A logical-for economists, perhaps even tautological-consequence of this is that constraints to movement are impediments to growth for whomever they happen to constrain. To estimate the migration premium, the regressions in tables 9 and 10 use initial household fixed effects. Any initial household and community characteristics are therefore a black box. Although this improves inference regarding the migration premium, it also offers an incomplete narrative of why certain people migrate and therefore 
Table 13.-Explaining Consumption Change: IHHFE, Moving out of Agriculture

\begin{tabular}{|c|c|c|c|}
\hline & $\begin{array}{c}(1) \\
\text { IHHFE }\end{array}$ & $\begin{array}{c}(2) \\
\text { IHHFE }\end{array}$ & $\begin{array}{c}(3) \\
\text { IHHFE }\end{array}$ \\
\hline \multicolumn{4}{|l|}{ Characteristics of the move } \\
\hline Moved outside community & & $\begin{array}{l}0.195 * * * \\
(0.034)\end{array}$ & \\
\hline Kilometers moved (log of distance) & & & $\begin{array}{l}0.073 * * * \\
(0.011)\end{array}$ \\
\hline Moved out of agriculture & $\begin{array}{l}0.407 * * * \\
(0.034)\end{array}$ & $\begin{array}{l}0.126^{* * * *} \\
(0.044)\end{array}$ & $\begin{array}{l}0.175 * * * \\
(0.040)\end{array}$ \\
\hline Moved outside community and out of agriculture & & $\begin{array}{l}0.449 * * * \\
(0.059)\end{array}$ & \\
\hline Distance moved $\times$ moved out of agriculture & & & $\begin{array}{l}0.075 \text { *** } \\
(0.015)\end{array}$ \\
\hline \multicolumn{4}{|l|}{ Individual characteristics at baseline } \\
\hline Deviation of years schooling from peers & $\begin{array}{c}0.013^{*} \\
(0.007)\end{array}$ & $\begin{array}{c}0.011^{*} \\
(0.006)\end{array}$ & $\begin{array}{c}0.010 \\
(0.006)\end{array}$ \\
\hline Squared deviation of years schooling from peers & $\begin{array}{l}0.004 * * \\
(0.002)\end{array}$ & $\begin{array}{l}0.003 * * \\
(0.001)\end{array}$ & $\begin{array}{l}0.003 * * \\
(0.001)\end{array}$ \\
\hline Male & $\begin{array}{c}-0.059 \\
(0.042)\end{array}$ & $\begin{array}{c}-0.020 \\
(0.040)\end{array}$ & $\begin{array}{c}-0.030 \\
(0.040)\end{array}$ \\
\hline Unmarried & $\begin{array}{c}-0.005 \\
(0.063)\end{array}$ & $\begin{array}{c}-0.059 \\
(0.061)\end{array}$ & $\begin{array}{c}-0.049 \\
(0.060)\end{array}$ \\
\hline Unmarried male & $\begin{array}{c}0.079 \\
(0.051)\end{array}$ & $\begin{array}{l}0.128 * * \\
(0.050)\end{array}$ & $\begin{array}{l}0.132 * * * \\
(0.049)\end{array}$ \\
\hline Both parents died & $\begin{array}{r}-0.066 \\
(0.113)\end{array}$ & $\begin{array}{c}-0.045 \\
(0.108)\end{array}$ & $\begin{array}{c}-0.022 \\
(0.108)\end{array}$ \\
\hline Above 15 and both parents died & $\begin{array}{c}0.110 \\
(0.126)\end{array}$ & $\begin{array}{c}0.076 \\
(0.121)\end{array}$ & $\begin{array}{c}0.045 \\
(0.120)\end{array}$ \\
\hline Years of education mother & $\begin{array}{c}0.005 \\
(0.007)\end{array}$ & $\begin{array}{r}-0.002 \\
(0.007)\end{array}$ & $\begin{array}{c}-0.005 \\
(0.007)\end{array}$ \\
\hline Years of education father & $\begin{array}{c}-0.003 \\
(0.006)\end{array}$ & $\begin{array}{c}0.001 \\
(0.006)\end{array}$ & $\begin{array}{c}0.000 \\
(0.006)\end{array}$ \\
\hline \multicolumn{4}{|l|}{ Biological children residing in household at baseline } \\
\hline Male children $0-5$ & $\begin{array}{r}-0.048 \\
(0.035)\end{array}$ & $\begin{array}{r}-0.047 \\
(0.034)\end{array}$ & $\begin{array}{r}-0.044 \\
(0.033)\end{array}$ \\
\hline Female children $0-5$ & $\begin{array}{r}-0.029 \\
(0.034)\end{array}$ & $\begin{array}{c}-0.018 \\
(0.033)\end{array}$ & $\begin{array}{c}-0.020 \\
(0.033)\end{array}$ \\
\hline Male children 6-10 & $\begin{array}{c}0.023 \\
(0.039)\end{array}$ & $\begin{array}{c}0.014 \\
(0.038)\end{array}$ & $\begin{array}{c}0.024 \\
(0.037)\end{array}$ \\
\hline Female children $6-10$ & $\begin{array}{c}-0.057 \\
(0.043)\end{array}$ & $\begin{array}{c}-0.056 \\
(0.041)\end{array}$ & $\begin{array}{c}-0.067 \\
(0.041)\end{array}$ \\
\hline Male children 11-15 & $\begin{array}{c}0.018 \\
(0.041)\end{array}$ & $\begin{array}{c}0.010 \\
(0.039)\end{array}$ & $\begin{array}{c}0.023 \\
(0.039)\end{array}$ \\
\hline Female children $11-15$ & $\begin{array}{c}0.004 \\
(0.039)\end{array}$ & $\begin{array}{c}0.010 \\
(0.037)\end{array}$ & $\begin{array}{c}0.008 \\
(0.037)\end{array}$ \\
\hline Male children 16-20 & $\begin{array}{c}-0.024 \\
(0.046)\end{array}$ & $\begin{array}{c}-0.009 \\
(0.044)\end{array}$ & $\begin{array}{c}-0.011 \\
(0.044)\end{array}$ \\
\hline Female children 16-20 & $\begin{array}{c}-0.100 * * \\
(0.049)\end{array}$ & $\begin{array}{c}-0.103 * * \\
(0.047)\end{array}$ & $\begin{array}{c}-0.111 * * \\
(0.047)\end{array}$ \\
\hline Male children $21+$ & $\begin{array}{c}0.027 \\
(0.053)\end{array}$ & $\begin{array}{c}0.013 \\
(0.051)\end{array}$ & $\begin{array}{c}0.005 \\
(0.050)\end{array}$ \\
\hline Female children $21+$ & $\begin{array}{c}-0.141 * * \\
(0.067)\end{array}$ & $\begin{array}{c}-0.103 \\
(0.064)\end{array}$ & $\begin{array}{c}-0.119 * \\
(0.064)\end{array}$ \\
\hline Number of children residing outside household & $\begin{array}{c}0.006 \\
(0.013)\end{array}$ & $\begin{array}{c}0.004 \\
(0.012)\end{array}$ & $\begin{array}{c}0.004 \\
(0.012)\end{array}$ \\
\hline Kilometers from regional capital $\times$ number outside children & $\begin{array}{c}0.000 \\
(0.000)\end{array}$ & $\begin{array}{c}0.000 \\
(0.000)\end{array}$ & $\begin{array}{c}0.000 \\
(0.000)\end{array}$ \\
\hline Age at baseline (1991-1994) & & & \\
\hline $5-15$ years & $\begin{array}{l}0.177 * * * \\
(0.049)\end{array}$ & $\begin{array}{l}0.132 * * * \\
(0.047)\end{array}$ & $\begin{array}{l}0.135^{* * * *} \\
(0.047)\end{array}$ \\
\hline $16-25$ years & $\begin{array}{c}0.058 \\
(0.057)\end{array}$ & $\begin{array}{c}0.029 \\
(0.055)\end{array}$ & $\begin{array}{c}0.029 \\
(0.054)\end{array}$ \\
\hline $26-35$ years & $\begin{array}{c}0.063 \\
(0.083)\end{array}$ & $\begin{array}{c}0.082 \\
(0.079)\end{array}$ & $\begin{array}{c}0.078 \\
(0.079)\end{array}$ \\
\hline $36-45$ years & $\begin{array}{c}0.077 \\
(0.098)\end{array}$ & $\begin{array}{c}0.085 \\
(0.094)\end{array}$ & $\begin{array}{c}0.077 \\
(0.093)\end{array}$ \\
\hline $46-55$ years & $\begin{array}{c}0.103 \\
(0.110)\end{array}$ & $\begin{array}{c}0.128 \\
(0.106)\end{array}$ & $\begin{array}{c}0.133 \\
(0.105)\end{array}$ \\
\hline $56-65$ years & $\begin{array}{c}0.091 \\
(0.119)\end{array}$ & $\begin{array}{c}0.105 \\
(0.114)\end{array}$ & $\begin{array}{c}0.113 \\
(0.114)\end{array}$ \\
\hline $66+$ years & $\begin{array}{c}0.195 \\
(0.156)\end{array}$ & $\begin{array}{c}0.246^{*} \\
(0.149)\end{array}$ & $\begin{array}{c}0.233 \\
(0.148)\end{array}$ \\
\hline Constant & $\begin{array}{c}0.084 \\
(0.082)\end{array}$ & $\begin{array}{c}0.054 \\
(0.079)\end{array}$ & $\begin{array}{c}0.057 \\
(0.078)\end{array}$ \\
\hline Number of observations & 2,546 & 2,546 & 2,546 \\
\hline
\end{tabular}

Standard errors are in parentheses. Significance at $* * * 1 \%, * * 5 \%, * 10 \%$, 
why the migration premium remains so high. To explore this, we replaced the initial household fixed effect in table 10 by a set of household and community variables as measured at baseline. We include characteristics of the head of the household (age, sex, and years of education), household size, a dummy for whether the household is a farm household, and wealth characteristics (land for cultivation, consumption per capita, the value of the physical capital stock, and the flooring quality in the dwelling). The community variables included are the cluster (village) means of all the above characteristics, the distance to Bukoba (the regional capital), and whether the community is remote (defined as an area not closely connected to an urban center).

The results are shown in table 14 (only the additional variables are reported as inference on the role of individual characteristics was superior in table 10). The table offers the marginal effects from a probit regression on whether an individual moved and the coefficients from an OLS regression explaining the logarithm of the distance migrated.

We find suggestive evidence of some factors that matter for the migration decision. First, we find some weak evidence that migration is higher in communities where farming was still the most important activity for a higher number of families, at least with respect to the distance of moves (column 2). The median community in the sample has $83 \%$ of households mainly involved in agriculture. However, controlling for this, being a farmer decreases the probability of any move and the distance migrated. Those with more land do not migrate as far as those with less land. Taken together, this suggests that migration is to some extent driven by a move out of agricultural settings, but those not involved in agriculture and faced with land pressure are more likely to move away and move farther.

Second, the regression results reported in table 10 show that education matters in explaining the migration of the individual, but table 14 shows that the educational level of the family or community does not matter: there is no more or further migration from households or settings with more education. Similarly, although living in better-connected areas is positively associated with the probability of moving, it is not associated with distance, and being closer to the regional capital is not associated with either migration measure.

Finally, are there any wealth or credit constraint effects? Migration may be a costly activity, requiring a serious investment. It is also an indivisible investment. Thus, some households may not be able to afford any migration to take advantage of the high return or can afford to have only some members migrate. From figures 3, 4, and 5, the samples of future movers and nonmovers started off with relatively similar wealth distributions. The evidence from table 14 is mixed. Among the household indicators, only the value of physical assets is associated negatively with moving. Neither consumption per capita nor good flooring is associated with migration. None of the community-mean wealth variables are statistically associated with migration.
Table 14.-Explaining Migration, Household, and Community Correlates

\begin{tabular}{|c|c|c|}
\hline & $\begin{array}{l}\text { (1) } \\
\text { Probit: } \\
\text { Moved out of } \\
\text { Community }\end{array}$ & $\begin{array}{c}\text { (2) } \\
\text { OLS: Kilometers } \\
\text { Moved (Log } \\
\text { of Distance) }\end{array}$ \\
\hline Sex of household head & $\begin{array}{c}0.012 \\
(0.026)\end{array}$ & $\begin{array}{c}-0.105 \\
(0.093)\end{array}$ \\
\hline Age of household head & $\begin{array}{c}0.001 \\
(0.001)\end{array}$ & $\begin{array}{l}0.009 \text { *** } \\
(0.002)\end{array}$ \\
\hline Education of household head & $\begin{array}{l}-0.005 \\
(0.004)\end{array}$ & $\begin{array}{c}0.000 \\
(0.015)\end{array}$ \\
\hline Household size & $\begin{array}{c}-0.000 \\
(0.003)\end{array}$ & $\begin{array}{c}-0.014 \\
(0.012)\end{array}$ \\
\hline Primary occupation is farming & $\begin{array}{c}-0.064 * * \\
(0.031)\end{array}$ & $\begin{array}{c}-0.355^{* * *} \\
(0.099)\end{array}$ \\
\hline Acres of land cultivated & $\begin{array}{c}-0.003 \\
(0.002)\end{array}$ & $\begin{array}{c}-0.014 * \\
(0.008)\end{array}$ \\
\hline $\begin{array}{l}\text { Consumption per capita } \\
\text { (in millions of TSh) }\end{array}$ & $\begin{array}{c}-0.021 \\
(0.124)\end{array}$ & $\begin{array}{c}-0.674 \\
(0.419)\end{array}$ \\
\hline $\begin{array}{l}\text { Value of physical assets } \\
\text { (in millions of TSh) }\end{array}$ & $\begin{array}{c}-0.008^{*} \\
(0.005)\end{array}$ & $\begin{array}{c}-0.024^{*} \\
(0.014)\end{array}$ \\
\hline Good flooring in dwelling & $\begin{array}{c}-0.003 \\
(0.031)\end{array}$ & $\begin{array}{c}0.097 \\
(0.105)\end{array}$ \\
\hline Kilometers from cluster to Bukoba & $\begin{array}{c}-0.000 \\
(0.000)\end{array}$ & $\begin{array}{r}-0.000 \\
(0.001)\end{array}$ \\
\hline Remote community & $\begin{array}{c}-0.047 * * \\
(0.020)\end{array}$ & $\begin{array}{c}-0.078 \\
(0.068)\end{array}$ \\
\hline \multicolumn{3}{|c|}{ Cluster mean of household characteristics } \\
\hline Sex of household head & $\begin{array}{c}-0.207^{*} \\
(0.120)\end{array}$ & $\begin{array}{c}0.068 \\
(0.411)\end{array}$ \\
\hline Age of household head & $\begin{array}{c}0.002 \\
(0.002)\end{array}$ & $\begin{array}{l}0.017 * * \\
(0.008)\end{array}$ \\
\hline Education of household head & $\begin{array}{c}0.005 \\
(0.013)\end{array}$ & $\begin{array}{c}0.017 \\
(0.043)\end{array}$ \\
\hline Household size & $\begin{array}{c}0.007 \\
(0.008)\end{array}$ & $\begin{array}{c}0.049^{*} \\
(0.028)\end{array}$ \\
\hline Primary occupation is farming & $\begin{array}{c}0.110 \\
(0.087)\end{array}$ & $\begin{array}{c}0.500 * \\
(0.289)\end{array}$ \\
\hline Acres of land cultivated & $\begin{array}{c}-0.001 \\
(0.007)\end{array}$ & $\begin{array}{c}-0.012 \\
(0.023)\end{array}$ \\
\hline $\begin{array}{l}\text { Consumption per capita } \\
\text { (in millions of TSh) }\end{array}$ & $\begin{array}{c}0.256 \\
(0.362)\end{array}$ & $\begin{array}{c}1.545 \\
(1.224)\end{array}$ \\
\hline $\begin{array}{l}\text { Value of physical assets } \\
\text { (in millions of TSh) }\end{array}$ & $\begin{array}{c}0.007 \\
(0.015)\end{array}$ & $\begin{array}{c}0.013 \\
(0.053)\end{array}$ \\
\hline Good flooring in dwelling & $\begin{array}{c}-0.028 \\
(0.084)\end{array}$ & $\begin{array}{c}-0.152 \\
(0.286)\end{array}$ \\
\hline Constant & & $\begin{array}{c}-0.825 \\
(0.755)\end{array}$ \\
\hline Number of observations & 3,119 & 3,119 \\
\hline
\end{tabular}

Standard errors are in parentheses. Significance at $* * * 1 \%, * * 5 \%, * 10 \%$. Column 1 presents the marginal effects from a probit estimation. Individual characteristics included in table 10 specifications are also included here, but are not presented in the table. The sample is slightly reduced (from 3,227) due to missing information on baseline value of physical stock for 108 households.

Overall, there is little evidence of credit or wealth constraints; if anything, there is a tendency for more migration from poorer households.

This still leaves open the question as to why more people do not migrate, given the high returns. The individual-level variables in the regressions in table 10 suggest that particular types of people within families can go and not others. Factors include individual education (with a convex effect), being unmarried and female (consistent with considerable migration for marriage by girls), being of a particular age group when rainfall shocks occur, and a series of positional variables in the household (including an age pecking order and gender effects). Distance to the regional capital, a migration pull factor, matters specifically for young males. 
There is scope for further interpretation of these findings within the local social context. The regressions suggest that an individual needs to be in a position to move in order to take advantage of geographic and time-specific economic opportunities, while at the same time a number of crucial social constraints in place may prevent an individual from doing so. Social and family norms interacting with pull (nearby towns) and push (shocks) factors are determinants of who may be allowed (or chosen) to move.

There appear to be windows of opportunity-being in the right place at the right time- that certain categories of people can take advantage of: not having social and family constraints in a window of time when physical mobility has large payoffs. Missing these windows implies remaining trapped in a low-return environment. But this still begs the question of why we do not see more migration given these high returns and why barriers remain in place if they are welfare reducing.

Our results are consistent with the literature that links network externalities to poverty traps and so endogenizes exit barriers in the village. In Hoff and Sen (2006), the kinship group decides how high to set the exit barrier for its members. They start from the observation that kin who have moved and remain loyal to their kinship group at home will sometimes need to undertake actions with negative consequences for their employers (securing jobs for kin) or landlords (sharing housing). This creates an entry barrier for anyone with obvious, strong kinship ties to their home village. In order to overcome such entry barriers, an individual may have to sever ties with his or her kinship group, implying the loss of a productive element (from the kinship group's point of view). To avoid this ex ante, the kinship group may decide to manipulate exit barriers, raising them through social norms about migration in order not to lose productive members. Hoff and Sen's model finds that it may be in the interest of the kinship group to prevent some of its members from taking advantage of economic opportunities.

Our results offer an empirical qualification of this basic result and suggest that exit barriers are not equal over time because they depend on interactions among gender, age, age rank, and the degree of connectedness to the household head. Furthermore, our results suggest that exit barriers are binding constraints only when geographic and time-specific push or pull factors offer a window for economic advancement through migration.

Are our results consistent with standard models of migration? As in Harris and Todaro (1970), higher benefits appear to drive migration. In their model, the assumption of unemployment in the urban sector allows the persistence of a wage premium between urban and rural areas, linked to urban unemployment in a context of imperfect labor markets. In equilibrium, expected urban earnings (across workers and the unemployed) are equal to rural earnings (Harris \& Todaro, 1970). As a result, observing living standards in urban areas to be above those in rural areas would suggest that equilibrium has not yet been attained, with continuing streams of migrants, so our results are inconsistent with the migration equilibrium, provided that expectations reflect true conditions. ${ }^{8}$ We cannot discount that we may be observing the migration process in a state of disequilibrium as part of a dynamic adjustment process to a long-run equilibrium with equal returns in expectation. Nevertheless, the scale of the disequilibrium is not easily explained given the available data and the results in tables 10 and 13 .

Other interpretations can nevertheless be offered as to why migration may be limited despite high returns in consumption terms. Consumption may be a poor measure of the overall net welfare benefit of migration. People may find the alienation from their original home environment costly in subjective terms. For example, a recent resurvey of the ICRISAT households in six villages in Maharashtra and Andhra Pradesh in India used a similar tracking methodology to the current paper (Dercon, Krishnan, \& Krutikov, 2009). Tracking all the people living in the original 240 ICRISAT households from 1975 to 1984, the study found that by 2004, those who had migrated had a premium of about $20 \%$ in consumption, controlling for initial household fixed effects. However, again controlling for initial household fixed effects, there was a negative premium on being a migrant in regressions with subjective well-being or subjective assessment of overall wealth as the dependent variable. In short, migrants had higher consumption in real terms but lower subjective well-being compared with those from the same original households who did not migrate, possibly as if a premium in terms of the former is required to compensate for the latter. In such circumstances, there is no reason that the consumption of migrants would ever equate to the consumption of nonmigrants; a gap would remain.

\section{Conclusion}

This paper explores the impact of migration on poverty and living standards in Tanzania. We use a unique thirteenyear panel data set, offering information on split-off households and migrants. Assessing the impact of migration on living standards is particularly difficult because we cannot observe someone to be a migrant and remain in the original community at the same time. A relatively simple differ-

\footnotetext{
${ }^{8}$ In principle, deviation of the estimated average difference between urban and rural living standards expost could also be possible in equilibrium in a Harris-Todaro-style model. For this to explain the apparent less-than-optimal migration levels, it would need to be the case that the gap in living standards between urban and rural areas was expected to be much lower than is now apparent. This could come about if expectations were not rational; if there was an unexpected higher level of urban wages by 2004 ; or, for example, if there was much higher employment in wellpaid jobs. The premium seems to be too high for this to be a sufficient explanation, most likely because although urban wages may be high, unemployment levels for particular groups are also high. More than $20 \%$ of the urban population between ages 18 and 34 is unemployed, in the sense that they are looking for work and available for work. Unemployment is double this figure using the national definition, which includes those with marginal or precarious job situations (United Republic of Tanzania, 2007).
} 
ence-in-difference model is used to assess the impact of migration on consumption levels, thereby controlling for fixed individual heterogeneity in determining the level of consumption. Furthermore, we can identify the impact of migration on the growth rate of consumption using withinhousehold variation in the subsequent migration of individual members. This initial household fixed-effects estimator controls for the unobserved heterogeneity in the growth rate of consumption that is common among baseline household members. Finally, a number of specific individual factors are added as controls, and IV estimates are also presented. We avoid identifying the migration decision based on the household circumstances (such as shocks, distance to potential areas of destination, and existence of family networks) used in most studies of migration impacts, but that are unlikely to satisfy the exclusion restriction.

The identified effects are remarkably large and robust: migrants experienced 36 percentage points higher consumption growth compared with those who stayed behind. We also find that transfers from migrants to nonmigrating household members are relatively limited. We find suggestive evidence that it matters where one moves. Moving to more connected areas has substantially higher returns, but even moving to a less connected area is correlated with higher growth. Moving into nonagricultural activities contributes to consumption growth, but this growth is always greater in any sector or activity if the individual physically moved.

Relative to the theory, this paper offers evidence consistent with features in the original Lewis model, with persistent wage differentials, at least at this stage of the rural transformation. ${ }^{9}$ Relative to the new economics of migration, the evidence is less conclusive. The robust difference in welfare levels between those who migrated and those who did not is not consistent with either complete altruism or risk sharing, although it is possible that the results reflect partial risk sharing and some transfers. We offer suggestive evidence that some transfers indeed occur, but they are relatively limited from those who migrated long distances.

Because we have not constructed a structural model of migration (only a first stage in a 2SLS procedure), our evidence does not shed full light on the migration process. However, we provide suggestive evidence that withinfamily social structures matter for who gets the opportunity to migrate, how far they go, and who, therefore, can move up economically in Tanzania. This evidence also helps us to understand better how our results relate to the predictions of the Harris-Todaro model. Unlike the equilibrium conditions in Harris-Todaro, on average the premium on migration is positive and rather large: in expectation, earnings do not appear to be equalized, suggesting that equilibrium has not been obtained, and returns to migration remain high.

\footnotetext{
${ }^{9}$ This interpretation of Lewis (1954) is still debated, and not necessarily a feature of subsequent dual economy models. For a discussion, see Fields (2004).
}

There appear to be barriers to physical movement, so that potential returns are unexploited. Our evidence suggests that just as in Hoff and Sen (2006), some of these barriers may be exit barriers that result in less-than-efficient levels of migration. Alternatively, other welfare costs related to migration may also limit migration.

\section{REFERENCES}

Alderman, Harold, Jere R. Berman, Hans-Peter Kohler, John Maluccio, and Susan Cotts Watkins, "Attrition in Longitudinal Household Survey Data: Some Tests for Three Developing-Country Samples," Demographic Research 5:4 (2001), 79-124.

Beegle, Kathleen, "Economic Mobility in Indonesia and Vietnam: What Missing Data Can't Tell Us," mimeograph (2000).

Beegle, Kathleen, Joachim De Weerdt, and Stefan Dercon, "Kagera Health and Development Survey (KHDS), 2004, Basic Information Document," mimeograph (2006).

Clemens, Michael, and Lant Pritchett, "Income per Natural: Measuring Development for People Rather Than Places," Population and Development Review 34 (2008), 395-434.

De Weerdt, Joachim, "Moving out of Poverty in Tanzania: Evidence from Kagera," Journal of Development Studies 46 (2010), 331-349.

Demombynes, Gabriel, and Johannes Hoogeveen, "Growth, Inequality and Simulated Poverty Paths for Tanzania, 1992-2002," Journal of African Economies 16 (2007), 596-628.

Dercon, Stefan, Pramila Krishnan, and Sonya Krutikov, "Migration, Risk-Sharing and Subjective Well-Being," Oxford University, mimeograph (2009).

Fields, Gary S, "Dualism in the Labor Market: A Perspective on the Lewis Model after Half a Century," Manchester School 72 (2004), 724-735.

Harris, John, and Michael Todaro, "Migration, Unemployment and Development: A Two-Sector Analysis," American Economic Review 60 (1970), 126-142.

Hoff, Karla, and Arjit Sen, "The Kin System as a Poverty Trap?" (pp. 91-115), in Samuel Bowles, Steven Durlauf, and Karla Hoff (Eds.), Poverty Traps (Princeton, NJ: Princeton University Press, 2006).

Kilic, Talip, Gero Carletto, Benjamin Davis, and Alberto Zezza, "Investing Back Home: Return Migration and Business Ownership in Albania," Economics of Transition 17 (2009), 587-623.

Lewis, W. Arthur, "Economic Development with Unlimited Supplies of Labor," Manchester School 22 (1954), 139-191.

McKenzie, David, and Marcin J. Sasin, "Migration, Remittances and Human Capital: Conceptual and Empirical Challenges," World Bank Policy Research working paper no. 4272 (2007).

McKenzie, David, John Gibson, and Steven Stillman, "How Important Is Selection? Experimental v. Non-Experimental Measures of the Income Gains from Migration," Journal of the European Economic Association 8 (2010), 913-945.

Munshi, Kaivan, "Networks in the Modern Economy: Mexican Migrants in the United States Labor Market," Quarterly Journal of Economics 118 (2003), 549-597.

Rosenzweig, Mark, "Payoffs from Panels in Low-Income Countries: Economic Development and Economic Mobility," American Economic Review 93 (2003), 112-117.

Rosenzweig, Mark, and Oded Stark, "Consumption Smoothing, Migration, and Marriage: Evidence from Rural India," Journal of Political Economy 97 (1989), 905-926.

Stark, Oded, and David Bloom, "The New Economics of Labor Migration," American Economic Review 75 (1985), 173-178.

Stock, James, and Motohiro Yogo, "Testing for Weak Instruments in Linear IV Regression," NBER technical working paper no. 0284 (2002).

United Republic of Tanzania, “The Economic Report, 2004,” President's Office, Planning and Privitisations (2004).

"Analytical Report for the Integrated Labor Force Survey" (National Bureau of Statistics, Ministry of Planning, Economy and Empowerment, 2007).

World Bank, "User's Guide to the Kagera Health and Development Survey Datasets," mimeograph (2004). 
TABLE APPENDIX

Table A1.-Sample Means and Standard Deviations

\begin{tabular}{|c|c|c|}
\hline & Mean & s.d. \\
\hline Change in (logged) consumption per capita & 0.26 & $(0.77)$ \\
\hline Moved & 0.33 & $(0.47)$ \\
\hline Distance moved (kms) & 35.02 & $(145.01)$ \\
\hline Distance moved variable: $\log (\mathrm{kms}+1)$ & 1.06 & $(1.78)$ \\
\hline \multicolumn{3}{|l|}{ Baseline covariates: Excluded instruments } \\
\hline Head or spouse & 0.26 & $(0.44)$ \\
\hline Child of head & 0.49 & $(0.50)$ \\
\hline Male child of head & 0.25 & $(0.43)$ \\
\hline Age rank in household $\times$ age $5-15$ & 0.00 & $(0.00)$ \\
\hline $\begin{array}{l}\text { Kilometers from regional capital } \times \\
\text { male } \times \text { age } 5-15\end{array}$ & 12.04 & $(38.43)$ \\
\hline $\begin{array}{l}\text { Rainfall shock (annual centimeters } \\
\text { deviation) } \times \text { age } 5-15\end{array}$ & -18.51 & $(28.71)$ \\
\hline \multicolumn{3}{|l|}{ Individual characteristics at baseline } \\
\hline Deviation of years schooling from peers & -0.25 & $(2.24)$ \\
\hline $\begin{array}{l}\text { Squared deviation of years schooling } \\
\text { from peers }\end{array}$ & 5.08 & $(9.50)$ \\
\hline Male & 0.47 & $(0.50)$ \\
\hline Unmarried & 0.69 & $(0.46)$ \\
\hline Unmarried male & 0.36 & $(0.48)$ \\
\hline Both parents died & 0.05 & $(0.22)$ \\
\hline Above 15 and both parents died & 0.02 & $(0.15)$ \\
\hline Years of education mother & 2.72 & $(3.02)$ \\
\hline Years of education father & 4.23 & $(3.32)$ \\
\hline \multicolumn{3}{|c|}{ Biological children residing in household at baseline } \\
\hline Male children $0-5$ & 0.15 & $(0.45)$ \\
\hline Female children $0-5$ & 0.14 & $(0.45)$ \\
\hline Male children 6-10 & 0.10 & $(0.36)$ \\
\hline Female children $6-10$ & 0.09 & $(0.34)$ \\
\hline Male children 11-15 & 0.10 & $(0.36)$ \\
\hline Female children $11-15$ & 0.11 & $(0.38)$ \\
\hline Male children 16-20 & 0.06 & $(0.29)$ \\
\hline Female children $16-20$ & 0.06 & $(0.28)$ \\
\hline Male children $21+$ & 0.05 & $(0.26)$ \\
\hline Female children $21+$ & 0.04 & $(0.21)$ \\
\hline $\begin{array}{l}\text { Number of children residing outside } \\
\text { household }\end{array}$ & 0.64 & $(1.83)$ \\
\hline $\begin{array}{l}\text { Kilometers from regional capital } \times \text { number } \\
\text { outside children }\end{array}$ & 44.62 & $(184.60)$ \\
\hline \multicolumn{3}{|l|}{ Age at baseline (1991-1994) } \\
\hline $5-15$ years & 0.35 & $(0.48)$ \\
\hline $16-25$ years & 0.20 & $(0.40)$ \\
\hline $26-35$ years & 0.08 & $(0.27)$ \\
\hline $36-45$ years & 0.07 & $(0.26)$ \\
\hline $46-55$ years & 0.06 & $(0.23)$ \\
\hline $56-65$ years & 0.04 & $(0.20)$ \\
\hline $66+$ years & 0.02 & $(0.12)$ \\
\hline Number of observations & \multicolumn{2}{|c|}{3,227} \\
\hline
\end{tabular}

Table A2.-Alternative Sets of Instrumental Variables

\begin{tabular}{|c|c|c|c|c|c|c|c|}
\hline & \multirow[b]{2}{*}{ All Included } & \multicolumn{6}{|c|}{ Excluded Instrumental Variable: } \\
\hline & & $\begin{array}{l}\text { Head or } \\
\text { Spouse }\end{array}$ & $\begin{array}{c}\text { Child of } \\
\text { Head }\end{array}$ & $\begin{array}{c}\text { Male Child } \\
\text { of Head }\end{array}$ & $\begin{array}{l}\text { Age Rank in } \\
\text { Household } \times \\
\text { Age } 5-15\end{array}$ & $\begin{array}{c}\text { Kilometers from } \\
\text { Regional Capital } \times \\
\text { Male } \times \text { Age } 5-15\end{array}$ & $\begin{array}{c}\text { Avgerage } \\
\text { Rainfall Shock } \times \\
\text { Age 5-15 }\end{array}$ \\
\hline \multicolumn{8}{|c|}{ Moved outside community } \\
\hline Coefficient & 0.38 & 0.40 & 0.49 & 0.30 & 0.32 & 0.38 & 0.36 \\
\hline Standard error & 0.15 & 0.20 & 0.16 & 0.16 & 0.15 & 0.16 & 0.16 \\
\hline Cragg-Donald & 11.86 & 7.62 & 12.36 & 12.32 & 13.58 & 12.54 & 12.89 \\
\hline \multicolumn{8}{|c|}{ Kilometers moved (log of distance) } \\
\hline Coefficient & 0.10 & 0.10 & 0.16 & 0.08 & 0.08 & 0.10 & 0.10 \\
\hline Standard error & 0.04 & 0.05 & 0.05 & 0.05 & 0.04 & 0.04 & 0.05 \\
\hline Cragg-Donald & 9.33 & 7.45 & 8.81 & 10.11 & 10.29 & 10.23 & 9.87 \\
\hline
\end{tabular}


Table A3.-Explaining Consumption Change: IHHFE and 2SLS, Household-Level Results

\begin{tabular}{|c|c|c|c|c|}
\hline & $\begin{array}{c}(1) \\
\text { IHHFE }\end{array}$ & $\begin{array}{c}(2) \\
\text { IHHFE }\end{array}$ & $\begin{array}{c}(3) \\
2 S L S\end{array}$ & $\begin{array}{c}(4) \\
2 S L S\end{array}$ \\
\hline Moved outside community & $\begin{array}{l}0.321 * * * \\
(0.038)\end{array}$ & & $\begin{array}{l}0.520^{* * * *} \\
(0.154)\end{array}$ & \\
\hline Kilometers moved (log of distance) & & $\begin{array}{l}0.112 \text { *** } \\
(0.009)\end{array}$ & & $\begin{array}{l}0.146^{* * * *} \\
(0.045)\end{array}$ \\
\hline \multicolumn{5}{|l|}{ Individual characteristics at baseline } \\
\hline Deviation of years schooling from peers & $\begin{array}{l}0.013 \\
(0.010)\end{array}$ & $\begin{array}{c}0.007 \\
(0.010)\end{array}$ & $\begin{array}{c}0.011 \\
(0.010)\end{array}$ & $\begin{array}{l}0.005 \\
(0.010)\end{array}$ \\
\hline Squared deviation of years schooling from peers & $\begin{array}{l}0.006^{* * * *} \\
(0.002)\end{array}$ & $\begin{array}{l}0.006^{* * * *} \\
(0.002)\end{array}$ & $\begin{array}{l}0.006^{* * * *} \\
(0.002)\end{array}$ & $\begin{array}{l}0.005^{* *} * \\
(0.002)\end{array}$ \\
\hline Male & $\begin{array}{l}0.085 \\
(0.096)\end{array}$ & $\begin{array}{c}0.067 \\
(0.093)\end{array}$ & $\begin{array}{l}0.115 \\
(0.098)\end{array}$ & $\begin{array}{c}0.076 \\
(0.093)\end{array}$ \\
\hline Unmarried & $\begin{array}{c}-0.114 \\
(0.101)\end{array}$ & $\begin{array}{r}-0.117 \\
(0.098)\end{array}$ & $\begin{array}{c}-0.144 \\
(0.104)\end{array}$ & $\begin{array}{c}-0.132 \\
(0.100)\end{array}$ \\
\hline Unmarried male & $\begin{array}{c}0.179 * \\
(0.102)\end{array}$ & $\begin{array}{c}0.182 * \\
(0.099)\end{array}$ & $\begin{array}{l}0.208^{* *} \\
(0.104)\end{array}$ & $\begin{array}{l}0.197 * * \\
(0.101)\end{array}$ \\
\hline Both parents died & $\begin{array}{c}-0.079 \\
(0.136)\end{array}$ & $\begin{array}{c}-0.042 \\
(0.133)\end{array}$ & $\begin{array}{c}-0.080 \\
(0.136)\end{array}$ & $\begin{array}{c}-0.032 \\
(0.133)\end{array}$ \\
\hline Above 15 and both parents died & $\begin{array}{c}0.124 \\
(0.175)\end{array}$ & $\begin{array}{c}0.066 \\
(0.171)\end{array}$ & $\begin{array}{c}0.092 \\
(0.177)\end{array}$ & $\begin{array}{c}0.034 \\
(0.175)\end{array}$ \\
\hline Years of education mother & $\begin{array}{r}-0.004 \\
(0.010)\end{array}$ & $\begin{array}{r}-0.006 \\
(0.009)\end{array}$ & $\begin{array}{c}-0.008 \\
(0.010)\end{array}$ & $\begin{array}{r}-0.009 \\
(0.010)\end{array}$ \\
\hline Years of education father & $\begin{array}{c}0.016 * \\
(0.009)\end{array}$ & $\begin{array}{c}0.015^{*} \\
(0.009)\end{array}$ & $\begin{array}{c}0.017 * \\
(0.009)\end{array}$ & $\begin{array}{c}0.015^{*} \\
(0.009)\end{array}$ \\
\hline Biological children residing in household at baseline & & & & \\
\hline Male children $0-5$ & $\begin{array}{c}-0.049 \\
(0.074)\end{array}$ & $\begin{array}{c}-0.042 \\
(0.072)\end{array}$ & $\begin{array}{c}-0.049 \\
(0.074)\end{array}$ & $\begin{array}{r}-0.040 \\
(0.072)\end{array}$ \\
\hline Female children $0-5$ & $\begin{array}{c}0.014 \\
(0.078)\end{array}$ & $\begin{array}{c}0.019 \\
(0.076)\end{array}$ & $\begin{array}{c}0.040 \\
(0.081)\end{array}$ & $\begin{array}{c}0.034 \\
(0.078)\end{array}$ \\
\hline Male children 6-10 & $\begin{array}{r}-0.112 \\
(0.090)\end{array}$ & $\begin{array}{c}-0.097 \\
(0.087)\end{array}$ & $\begin{array}{c}-0.101 \\
(0.090)\end{array}$ & $\begin{array}{c}-0.087 \\
(0.088)\end{array}$ \\
\hline Female children $6-10$ & $\begin{array}{c}-0.181^{*} \\
(0.090)\end{array}$ & $\begin{array}{c}-0.209 * * \\
(0.088)\end{array}$ & $\begin{array}{c}-0.179 * \\
(0.090)\end{array}$ & $\begin{array}{c}-0.216^{* *} \\
(0.088)\end{array}$ \\
\hline Male children 11-15 & $\begin{array}{c}0.046 \\
(0.076)\end{array}$ & $\begin{array}{c}0.051 \\
(0.074)\end{array}$ & $\begin{array}{c}0.042 \\
(0.076)\end{array}$ & $\begin{array}{l}0.051 \\
(0.073)\end{array}$ \\
\hline Female children $11-15$ & $\begin{array}{r}-0.046 \\
(0.083)\end{array}$ & $\begin{array}{r}-0.045 \\
(0.081)\end{array}$ & $\begin{array}{r}-0.018 \\
(0.086)\end{array}$ & $\begin{array}{r}-0.031 \\
(0.082)\end{array}$ \\
\hline Male children 16-20 & $\begin{array}{c}0.040 \\
(0.088)\end{array}$ & $\begin{array}{c}0.024 \\
(0.086)\end{array}$ & $\begin{array}{c}0.054 \\
(0.089)\end{array}$ & $\begin{array}{c}0.026 \\
(0.085)\end{array}$ \\
\hline Female children 16-20 & $\begin{array}{c}-0.200^{* *} \\
(0.105)\end{array}$ & $\begin{array}{c}-0.214^{* *} \\
(0.102)\end{array}$ & $\begin{array}{c}-0.174^{*} \\
(0.107)\end{array}$ & $\begin{array}{c}-0.206^{* * *} \\
(0.102)\end{array}$ \\
\hline Male children $21+$ & $\begin{array}{c}0.046 \\
(0.105)\end{array}$ & $\begin{array}{c}0.041 \\
(0.102)\end{array}$ & $\begin{array}{c}0.035 \\
(0.105)\end{array}$ & $\begin{array}{c}0.035 \\
(0.102)\end{array}$ \\
\hline Female children $21+$ & $\begin{array}{r}-0.204 \\
(0.126)\end{array}$ & $\begin{array}{c}-0.237^{*} \\
(0.122)\end{array}$ & $\begin{array}{r}-0.166 \\
(0.129)\end{array}$ & $\begin{array}{c}-0.229 * \\
(0.122)\end{array}$ \\
\hline Number of children residing outside household & $\begin{array}{c}-0.001 \\
(0.022)\end{array}$ & $\begin{array}{l}0.001 \\
(0.021)\end{array}$ & $\begin{array}{r}-0.004 \\
(0.022)\end{array}$ & $\begin{array}{c}0.000 \\
(0.021)\end{array}$ \\
\hline Kilometers from regional capital $\times$ number outside children & $\begin{array}{c}0.000 \\
(0.000)\end{array}$ & $\begin{array}{c}0.000 \\
(0.000)\end{array}$ & $\begin{array}{c}0.000 \\
(0.000)\end{array}$ & $\begin{array}{c}0.000 \\
(0.000)\end{array}$ \\
\hline Age at baseline (1991-1994) & & & & \\
\hline $5-15$ years & $\begin{array}{l}0.245^{* * * *} \\
(0.062)\end{array}$ & $\begin{array}{l}0.246^{* * * *} \\
(0.060)\end{array}$ & $\begin{array}{l}0.215^{* * * *} \\
(0.066)\end{array}$ & $\begin{array}{l}0.229 * * * \\
(0.063)\end{array}$ \\
\hline $16-25$ years & $\begin{array}{l}0.060 \\
(0.071)\end{array}$ & $\begin{array}{c}0.066 \\
(0.069)\end{array}$ & $\begin{array}{l}0.047 \\
(0.072)\end{array}$ & $\begin{array}{c}0.058 \\
(0.069)\end{array}$ \\
\hline $26-35$ years & $\begin{array}{c}0.152 \\
(0.131)\end{array}$ & $\begin{array}{c}0.160 \\
(0.127)\end{array}$ & $\begin{array}{c}0.196 \\
(0.135)\end{array}$ & $\begin{array}{c}0.183 \\
(0.130)\end{array}$ \\
\hline $36-45$ years & $\begin{array}{c}0.141 \\
(0.168)\end{array}$ & $\begin{array}{c}0.167 \\
(0.163)\end{array}$ & $\begin{array}{c}0.155 \\
(0.168)\end{array}$ & $\begin{array}{c}0.161 \\
(0.163)\end{array}$ \\
\hline $46-55$ years & $\begin{array}{c}0.206 \\
(0.187)\end{array}$ & $\begin{array}{c}0.264 \\
(0.182)\end{array}$ & $\begin{array}{c}0.278 \\
(0.194)\end{array}$ & $\begin{array}{c}0.312^{*} \\
(0.193)\end{array}$ \\
\hline $56-65$ years & $\begin{array}{c}0.144 \\
(0.199)\end{array}$ & $\begin{array}{c}0.180 \\
(0.193)\end{array}$ & $\begin{array}{c}0.243 \\
(0.212)\end{array}$ & $\begin{array}{c}0.231 \\
(0.206)\end{array}$ \\
\hline $66+$ years & $\begin{array}{c}0.336 \\
(0.236)\end{array}$ & $\begin{array}{c}0.344 \\
(0.229)\end{array}$ & $\begin{array}{c}0.384 * \\
(0.238)\end{array}$ & $\begin{array}{c}0.357 \\
(0.230)\end{array}$ \\
\hline Constant & $\begin{array}{c}0.025 \\
(0.129)\end{array}$ & $\begin{array}{c}0.019 \\
(0.125)\end{array}$ & & \\
\hline Cragg-Donald & & & 13.68 & 9.10 \\
\hline Sargan statistic & & & 5.67 & 7.76 \\
\hline Sargan $p$-value & & & 0.34 & 0.17 \\
\hline Number of observations & 1,909 & 1,909 & 1,909 & 1,909 \\
\hline
\end{tabular}




\begin{tabular}{|c|c|c|}
\hline & $\begin{array}{c}(1) \\
\text { Moved }\end{array}$ & $\begin{array}{c}(2) \\
\text { Distance Moved }\end{array}$ \\
\hline \multicolumn{3}{|l|}{ Baseline covariates: excluded instruments } \\
\hline Head or spouse & $\begin{array}{c}-0.179 * * * \\
(0.063)\end{array}$ & $\begin{array}{c}-0.479^{*} \\
(0.254)\end{array}$ \\
\hline Child of head & $\begin{array}{c}-0.058 \\
(0.048)\end{array}$ & $\begin{array}{c}-0.343^{*} \\
(0.193)\end{array}$ \\
\hline Male child of head & $\begin{array}{l}-0.157 * * * \\
(0.056)\end{array}$ & $\begin{array}{l}-0.455^{* *} \\
(0.227)\end{array}$ \\
\hline Age rank in household $\times$ age $5-15$ & $\begin{array}{l}-7.379 \\
(12.036)\end{array}$ & $\begin{array}{l}-1.269 \\
(48.763)\end{array}$ \\
\hline Kilometers from regional capital $\times$ male $\times$ age $5-15$ & $\begin{array}{c}-0.001 * \\
(0.000)\end{array}$ & $\begin{array}{c}-0.001 \\
(0.001)\end{array}$ \\
\hline Rainfall shock $\times$ age $5-15$ & $\begin{array}{l}0.001 * * * \\
(0.000)\end{array}$ & $\begin{array}{l}0.002^{* * * *} \\
(0.000)\end{array}$ \\
\hline \multicolumn{3}{|l|}{ Individual characteristics at baseline } \\
\hline Deviation of years schooling from peers & $\begin{array}{c}0.007 \\
(0.007)\end{array}$ & $\begin{array}{l}0.070 * * \\
(0.030)\end{array}$ \\
\hline Squared deviation of years schooling from peers & $\begin{array}{l}0.003 * * \\
(0.002)\end{array}$ & $\begin{array}{l}0.018 * * * \\
(0.006)\end{array}$ \\
\hline Male & $\begin{array}{c}-0.126^{*} \\
(0.070)\end{array}$ & $\begin{array}{c}-0.233 \\
(0.282)\end{array}$ \\
\hline Unmarried & $\begin{array}{c}0.095 \\
(0.075)\end{array}$ & $\begin{array}{c}0.364 \\
(0.306)\end{array}$ \\
\hline Unmarried male & $\begin{array}{c}-0.022 \\
(0.079)\end{array}$ & $\begin{array}{c}-0.073 \\
(0.322)\end{array}$ \\
\hline Both parents died & $\begin{array}{c}0.019 \\
(0.098)\end{array}$ & $\begin{array}{c}-0.276 \\
(0.396)\end{array}$ \\
\hline Above 15 and both parents died & $\begin{array}{l}0.160 \\
(0.125)\end{array}$ & $\begin{array}{l}0.974 * \\
(0.507)\end{array}$ \\
\hline Years of education mother & $\begin{array}{l}0.015 * * \\
(0.007)\end{array}$ & $\begin{array}{l}0.060 * * \\
(0.028)\end{array}$ \\
\hline Years of education father & $\begin{array}{c}-0.010 \\
(0.007)\end{array}$ & $\begin{array}{c}-0.019 \\
(0.027)\end{array}$ \\
\hline \multicolumn{3}{|l|}{ Biological children residing in household at baseline } \\
\hline Male children $0-5$ & $\begin{array}{c}0.016 \\
(0.053)\end{array}$ & $\begin{array}{c}-0.011 \\
(0.216)\end{array}$ \\
\hline Female children $0-5$ & $\begin{array}{c}-0.082 \\
(0.056)\end{array}$ & $\begin{array}{r}-0.246 \\
(0.229)\end{array}$ \\
\hline Male children 6-10 & $\begin{array}{c}-0.007 \\
(0.065)\end{array}$ & $\begin{array}{r}-0.162 \\
(0.263)\end{array}$ \\
\hline Female children 6-10 & $\begin{array}{c}0.005 \\
(0.066)\end{array}$ & $\begin{array}{c}0.221 \\
(0.267)\end{array}$ \\
\hline Male children 11-15 & $\begin{array}{c}0.037 \\
(0.055)\end{array}$ & $\begin{array}{c}0.045 \\
(0.224)\end{array}$ \\
\hline Female children $11-15$ & $\begin{array}{c}-0.087 \\
(0.061)\end{array}$ & $\begin{array}{c}-0.274 \\
(0.246)\end{array}$ \\
\hline Male children 16-20 & $\begin{array}{r}-0.061 \\
(0.063)\end{array}$ & $\begin{array}{r}-0.040 \\
(0.257)\end{array}$ \\
\hline Female children 16-20 & $\begin{array}{r}-0.105 \\
(0.075)\end{array}$ & $\begin{array}{r}-0.169 \\
(0.304)\end{array}$ \\
\hline Male children $21+$ & $\begin{array}{c}0.063 \\
(0.075)\end{array}$ & $\begin{array}{c}0.239 \\
(0.305)\end{array}$ \\
\hline Female children $21+$ & $\begin{array}{c}-0.156^{*} \\
(0.091)\end{array}$ & $\begin{array}{r}-0.168 \\
(0.369)\end{array}$ \\
\hline Number of children residing outside household & $\begin{array}{c}0.006 \\
(0.016)\end{array}$ & $\begin{array}{c}0.001 \\
(0.064)\end{array}$ \\
\hline Kilometers from regional capital $\times$ number outside children & $\begin{array}{l}0.000 * * \\
(0.000)\end{array}$ & $\begin{array}{l}0.001^{* *} \\
(0.000)\end{array}$ \\
\hline Age at baseline (1991-1994) & & \\
\hline $5-15$ years & $\begin{array}{l}0.454 * * * \\
(0.072)\end{array}$ & $\begin{array}{l}1.351 * * * \\
(0.292)\end{array}$ \\
\hline $16-25$ years & $\begin{array}{c}0.032 \\
(0.052)\end{array}$ & $\begin{array}{c}0.046 \\
(0.209)\end{array}$ \\
\hline $26-35$ years & $\begin{array}{c}-0.227 * * \\
(0.094)\end{array}$ & $\begin{array}{c}-0.745^{*} \\
(0.383)\end{array}$ \\
\hline $36-45$ years & $\begin{array}{c}-0.089 \\
(0.121)\end{array}$ & $\begin{array}{c}-0.389 \\
(0.491)\end{array}$ \\
\hline $46-55$ years & $\begin{array}{c}-0.340 * * \\
(0.135)\end{array}$ & $\begin{array}{l}-1.521 * * * \\
(0.548)\end{array}$ \\
\hline $56-65$ years & $\begin{array}{c}-0.433 * * * \\
(0.144)\end{array}$ & $\begin{array}{l}-1.549 * * * \\
(0.582)\end{array}$ \\
\hline $66+$ years & $\begin{array}{r}-0.239 \\
(0.170)\end{array}$ & $\begin{array}{c}-0.727 \\
(0.688)\end{array}$ \\
\hline Number of observations & 1,909 & 1,909 \\
\hline
\end{tabular}

Standard errors are in parentheses. Significance at $* * * 1 \%, * * 5 \%, * 10 \%$, 
Table A5.-Household Size at Baseline and Follow-Up, by Mobility Categories, Mean (Median)

\begin{tabular}{|c|c|c|c|c|c|}
\hline & \multicolumn{2}{|c|}{ Household Size } & \multicolumn{2}{|c|}{ Household Size: Adult Equivalent } & \multirow[b]{2}{*}{$N$} \\
\hline & 1991 & 2004 & 1991 & 2004 & \\
\hline \multirow[t]{2}{*}{ Same village } & 7.71 & 5.98 & 6.15 & 4.94 & 2,150 \\
\hline & $(7.0)$ & $(6.0)$ & $(5.7)$ & $(4.6)$ & \\
\hline \multirow[t]{2}{*}{ Neighboring community } & 8.20 & 4.93 & 6.59 & 3.87 & 400 \\
\hline & $(7.0)$ & $(5.0)$ & $(5.9)$ & $(3.4)$ & \\
\hline \multirow[t]{2}{*}{ Elsewhere in Kagera } & 7.65 & 4.47 & 6.17 & 3.55 & 437 \\
\hline & $(7.0)$ & $(4.0)$ & $(6.0)$ & $(3.2)$ & \\
\hline \multirow[t]{2}{*}{ Outside Kagera } & 8.45 & 4.45 & 6.74 & 3.69 & 251 \\
\hline & $(7.0)$ & $(4.0)$ & $(6.1)$ & $(3.1)$ & \\
\hline
\end{tabular}

Adult equivalence is defined following the National Bureau of Statistics with varying weights by age and sex.

Table A6.-Explaining Consumption Change: IHHFE and 2SlS Adult Equivalent Consumption (Rather Than Per Capita)

\begin{tabular}{|c|c|c|c|c|}
\hline & $\begin{array}{c}(1) \\
\text { IHHFE }\end{array}$ & $\begin{array}{c}(2) \\
\text { IHHFE }\end{array}$ & $\begin{array}{c}\text { (3) } \\
\text { 2SLS with IHHFE }\end{array}$ & $\begin{array}{c}\text { (4) } \\
\text { 2SLS with IHHFE }\end{array}$ \\
\hline Moved outside community & $\begin{array}{l}0.363 * * * \\
(0.024)\end{array}$ & & $\begin{array}{l}0.426^{* * * *} \\
(0.143)\end{array}$ & \\
\hline Kilometers moved (log of distance) & & $\begin{array}{l}0.117 * * * \\
(0.006)\end{array}$ & & $\begin{array}{l}0.123 * * * \\
(0.041)\end{array}$ \\
\hline \multicolumn{5}{|l|}{ Individual characteristics at baseline } \\
\hline Deviation of years schooling from peers & $\begin{array}{l}0.014 * * \\
(0.006)\end{array}$ & $\begin{array}{c}0.010^{*} \\
(0.006)\end{array}$ & $\begin{array}{l}0.013 * * \\
(0.006)\end{array}$ & $\begin{array}{c}0.010 \\
(0.006)\end{array}$ \\
\hline Squared deviation of years schooling from peers & $\begin{array}{l}0.004 * * * \\
(0.001)\end{array}$ & $\begin{array}{l}0.003 * * \\
(0.001)\end{array}$ & $\begin{array}{l}0.004 * * * \\
(0.001)\end{array}$ & $\begin{array}{l}0.003 * * \\
(0.001)\end{array}$ \\
\hline Male & $\begin{array}{c}-0.010 \\
(0.036)\end{array}$ & $\begin{array}{c}-0.016 \\
(0.035)\end{array}$ & $\begin{array}{c}-0.008 \\
(0.036)\end{array}$ & $\begin{array}{c}-0.016 \\
(0.035)\end{array}$ \\
\hline Unmarried & $\begin{array}{c}0.043 \\
(0.053)\end{array}$ & $\begin{array}{c}0.048 \\
(0.051)\end{array}$ & $\begin{array}{c}0.030 \\
(0.060)\end{array}$ & $\begin{array}{c}0.045 \\
(0.057)\end{array}$ \\
\hline Unmarried male & $\begin{array}{l}0.087 * * \\
(0.043)\end{array}$ & $\begin{array}{c}0.076^{*} \\
(0.041)\end{array}$ & $\begin{array}{c}0.099^{*} \\
(0.051)\end{array}$ & $\begin{array}{c}0.079 * \\
(0.046)\end{array}$ \\
\hline Both parents died & $\begin{array}{c}0.007 \\
(0.079)\end{array}$ & $\begin{array}{c}0.026 \\
(0.077)\end{array}$ & $\begin{array}{c}0.009 \\
(0.079)\end{array}$ & $\begin{array}{c}0.027 \\
(0.077)\end{array}$ \\
\hline Above 15 and both parents died & $\begin{array}{c}0.032 \\
(0.095)\end{array}$ & $\begin{array}{c}0.008 \\
(0.093)\end{array}$ & $\begin{array}{c}0.026 \\
(0.096)\end{array}$ & $\begin{array}{c}0.005 \\
(0.095)\end{array}$ \\
\hline Years of education mother & $\begin{array}{c}-0.002 \\
(0.005)\end{array}$ & $\begin{array}{c}-0.003 \\
(0.005)\end{array}$ & $\begin{array}{c}-0.003 \\
(0.006)\end{array}$ & $\begin{array}{c}-0.003 \\
(0.006)\end{array}$ \\
\hline Years of education father & $\begin{array}{c}0.008 * \\
(0.005)\end{array}$ & $\begin{array}{c}0.007 \\
(0.005)\end{array}$ & $\begin{array}{c}0.008^{*} \\
(0.005)\end{array}$ & $\begin{array}{c}0.007 \\
(0.005)\end{array}$ \\
\hline \multicolumn{5}{|l|}{ Biological children residing in household at baseline } \\
\hline Male children $0-5$ & $\begin{array}{c}-0.041 \\
(0.029)\end{array}$ & $\begin{array}{c}-0.041 \\
(0.028)\end{array}$ & $\begin{array}{c}-0.041 \\
(0.029)\end{array}$ & $\begin{array}{c}-0.041 \\
(0.028)\end{array}$ \\
\hline Female children $0-5$ & $\begin{array}{r}-0.027 \\
(0.028)\end{array}$ & $\begin{array}{r}-0.025 \\
(0.028)\end{array}$ & $\begin{array}{r}-0.027 \\
(0.028)\end{array}$ & $\begin{array}{r}-0.024 \\
(0.028)\end{array}$ \\
\hline Male children 6-10 & $\begin{array}{c}0.001 \\
(0.033)\end{array}$ & $\begin{array}{c}0.005 \\
(0.032)\end{array}$ & $\begin{array}{c}0.000 \\
(0.033)\end{array}$ & $\begin{array}{c}0.006 \\
(0.032)\end{array}$ \\
\hline Female children 6-10 & $\begin{array}{c}-0.042 \\
(0.036)\end{array}$ & $\begin{array}{c}-0.052 \\
(0.035)\end{array}$ & $\begin{array}{c}-0.042 \\
(0.035)\end{array}$ & $\begin{array}{c}-0.053 \\
(0.035)\end{array}$ \\
\hline Male children $11-15$ & $\begin{array}{c}0.001 \\
(0.034)\end{array}$ & $\begin{array}{c}0.005 \\
(0.033)\end{array}$ & $\begin{array}{c}0.001 \\
(0.034)\end{array}$ & $\begin{array}{c}0.005 \\
(0.033)\end{array}$ \\
\hline Female children $11-15$ & $\begin{array}{c}-0.014 \\
(0.033)\end{array}$ & $\begin{array}{c}-0.019 \\
(0.032)\end{array}$ & $\begin{array}{c}-0.011 \\
(0.033)\end{array}$ & $\begin{array}{c}-0.018 \\
(0.032)\end{array}$ \\
\hline Male children 16-20 & $\begin{array}{c}0.005 \\
(0.039)\end{array}$ & $\begin{array}{c}-0.003 \\
(0.038)\end{array}$ & $\begin{array}{c}0.006 \\
(0.039)\end{array}$ & $\begin{array}{c}-0.003 \\
(0.038)\end{array}$ \\
\hline Female children $16-20$ & $\begin{array}{c}-0.056 \\
(0.042)\end{array}$ & $\begin{array}{c}-0.064 \\
(0.041)\end{array}$ & $\begin{array}{c}-0.054 \\
(0.042)\end{array}$ & $\begin{array}{c}-0.064 \\
(0.041)\end{array}$ \\
\hline Male children $21+$ & $\begin{array}{c}0.013 \\
(0.043)\end{array}$ & $\begin{array}{c}0.006 \\
(0.042)\end{array}$ & $\begin{array}{c}0.011 \\
(0.043)\end{array}$ & $\begin{array}{c}0.005 \\
(0.042)\end{array}$ \\
\hline Female children $21+$ & $\begin{array}{c}-0.066 \\
(0.052)\end{array}$ & $\begin{array}{c}-0.087 * \\
(0.051)\end{array}$ & $\begin{array}{c}-0.063 \\
(0.053)\end{array}$ & $\begin{array}{c}-0.087 * \\
(0.051)\end{array}$ \\
\hline Number of children residing outside household & $\begin{array}{c}0.002 \\
(0.010)\end{array}$ & $\begin{array}{c}0.004 \\
(0.010)\end{array}$ & $\begin{array}{c}0.003 \\
(0.010)\end{array}$ & $\begin{array}{c}0.004 \\
(0.010)\end{array}$ \\
\hline Kilometers from regional capital $\times$ number outside children & $\begin{array}{c}0.000 \\
(0.000)\end{array}$ & $\begin{array}{c}0.000 \\
(0.000)\end{array}$ & $\begin{array}{c}0.000 \\
(0.000)\end{array}$ & $\begin{array}{c}0.000 \\
(0.000)\end{array}$ \\
\hline
\end{tabular}


MIGRATION AND ECONOMIC MOBILITY IN TANZANIA

TABLE A6.-(CONTINUED)

\begin{tabular}{|c|c|c|c|c|}
\hline & $\begin{array}{c}(1) \\
\text { IHHFE }\end{array}$ & $\begin{array}{c}(2) \\
\text { IHHFE }\end{array}$ & $\begin{array}{c}\text { (3) } \\
\text { 2SLS with IHHFE }\end{array}$ & $\begin{array}{c}\text { (4) } \\
\text { 2SLS with IHHFE }\end{array}$ \\
\hline \multicolumn{5}{|c|}{ Age at baseline (1991-1994) } \\
\hline \multirow[t]{2}{*}{$5-15$ years } & $0.200^{* * *}$ & $0.199 * * *$ & $0.187 * * *$ & $0.199 * * *$ \\
\hline & $(0.028)$ & $(0.027)$ & $(0.041)$ & $(0.038)$ \\
\hline \multirow[t]{2}{*}{$16-25$ years } & $0.175^{* * *}$ & $0.178 * * *$ & $0.163 * * *$ & $0.175^{* * *}$ \\
\hline & $(0.037)$ & $(0.036)$ & $(0.046)$ & $(0.043)$ \\
\hline \multirow[t]{2}{*}{$26-35$ years } & $0.192 * * *$ & $0.189 * * *$ & $0.188 * * *$ & $0.188 * * *$ \\
\hline & $(0.061)$ & $(0.060)$ & $(0.061)$ & $(0.060)$ \\
\hline \multirow[t]{2}{*}{$36-45$ years } & $0.197 * * *$ & $0.197 * * *$ & $0.190 * *$ & $0.195 * * *$ \\
\hline & $(0.075)$ & $(0.074)$ & $(0.077)$ & $(0.075)$ \\
\hline \multirow[t]{2}{*}{$46-55$ years } & $0.256^{* * *}$ & $0.270 * * *$ & $0.253^{* * *}$ & $0.270 * * *$ \\
\hline & $(0.086)$ & $(0.084)$ & $(0.086)$ & $(0.083)$ \\
\hline \multirow[t]{2}{*}{$56-65$ years } & $0.232 * *$ & $0.238 * * *$ & $0.231 * *$ & $0.238 * * *$ \\
\hline & $(0.093)$ & $(0.091)$ & $(0.093)$ & $(0.090)$ \\
\hline \multirow[t]{2}{*}{$66+$ years } & $0.313^{* * *}$ & $0.302 * * *$ & $0.310^{* * *}$ & $0.300 * * *$ \\
\hline & $(0.114)$ & $(0.112)$ & $(0.114)$ & $(0.111)$ \\
\hline \multirow[t]{2}{*}{ Constant } & $-0.137 * *$ & $-0.125^{* *}$ & & \\
\hline & $(0.061)$ & $(0.059)$ & & \\
\hline Cragg-Donald & & & 11.86 & 9.33 \\
\hline Sargan statistic & & & 10.59 & 11.44 \\
\hline Sargan $p$-value & & & 0.06 & 0.04 \\
\hline Number of observations & 3,227 & 3,227 & 3,227 & 3,227 \\
\hline
\end{tabular}

